\title{
Volcano-tectonic evolution of the Santa Maria Island (Azores): implications for palaeostress evolution at the western Eurasia- Nubia plate boundary
}

\author{
A.L.R. Sibrant ${ }^{1,2 *}$, A. Hildenbrand ${ }^{1,2}$, F.O. Marques ${ }^{3}$, A.C.G. Costa ${ }^{1,4}$ \\ (1) Université Paris-Sud, Laboratoire GEOPS, UMR8148, Orsay, F-91405 \\ (2) CNRS, Orsay, F-91405 \\ (3) Universidade de Lisboa, Lisboa, Portugal \\ (4) Universidade de Lisboa and IDL, Lisboa, Portugal \\ *Corresponding author. Tel.: +33169156761 \\ E-mail address: aurore.sibrant@laposte.net
}




\begin{abstract}
The growth and decay of oceanic volcanoes developed close to plate boundaries are intrinsically related to a competition between construction and destruction processes, partly controlled by tectonic strain and stresses. From morphologic, stratigraphic, tectonic and new highprecision K-Ar data, we present a comprehensive picture of the volcano-tectonic evolution of Santa Maria, and discuss its significance regarding the stress evolution and regional deformation in the Azores. Our new data show that: (1) the western flat portion of the island is mostly composed of west-dipping volcanic rocks here dated between $5.70 \pm 0.08$ and $5.33 \pm 0.08 \mathrm{Ma}$, which we consider the remnants of an Older Shield Volcano; (2) more than half of this early volcanic complex has been removed by an east-directed large-scale sector collapse; (3) a second volcano, here coined the Younger Shield Volcano, grew rapidly on the collapse scar between at least $4.32 \pm 0.06$ and $3.94 \pm$ $0.06 \mathrm{Ma}$; (4) more than half of this new volcano was removed by a second large-scale sector collapse most probably around 3.6 Ma, based on the ages of parasitic scoria cones sitting unconformably on the Younger Shield Volcano; (5) the latest parasitic volcanic activity is here dated at $2.84 \pm 0.04 \mathrm{Ma}$, extending significantly the known eruptive history of Santa Maria. Morpho-structural data (shape of the island, faults, dikes, and distribution of volcanic cones) show a significant control of construction and destruction along the $\mathrm{N} 045^{\circ}$ and $\mathrm{N} 150^{\circ}$ directions. The age of the lavas intruded by dikes suggests that the $\mathrm{N} 045^{\circ}$ and the $\mathrm{N} 150^{\circ}$ trends are ca. $5.3 \mathrm{Ma}$ old and younger than ca. 4.3 Ma, respectively. Based on the new data, we conclude that a change in the regional stress field occurred between 5.3 and 4.3 Ma, most likely associated with a major reconfiguration of the Eurasia/Nubia plate boundary in the Azores.
\end{abstract}

Keywords: Santa Maria Island; K-Ar geochronology; dikes; flank collapse; Azores Triple Junction; Eurasia/Nubia plate boundary. 


\section{Introduction}

The evolution of volcanic ocean islands generally occurs in a complex way, as a result of a competition between volcanic construction and destruction processes. The growth of large intraplate volcanoes, especially, is often punctuated by episodes of gravitational destabilization in the form of catastrophic flank collapses, as extensively recognized worlwide: Hawaii (e.g. Moore et al., 1989; 1995), the Canary islands (e.g. Carracedo, 1994; Carracedo et al., 1999; Boulesteix et al., 2012, 2013), or in the Cape Verde (e.g., Masson et al., 2008; Ancochea et al., 2010). Closer to major plate boundaries, the evolution of oceanic volcanoes may additionnaly be significantly influenced by regional deformation. This seems to be the case in the Azores volcanic archipelago near the present Triple Junction between the North American (NA), the Eurasian (EU) and the Nubian (NU) lithospheric plates. Recent studies on the most recent islands of the archipelago have shown that recent volcanic construction and destruction episodes have been significantly focused along major active regional structures (e.g., Lourenço et al., 1998; Haase and Beier, 2003; Hildenbrand et al., 2008a; 2012a,b; 2013a,b; Navarro et al., 2009; Quartau et al., 2012; Marques et al., 2013a; 2014a; Costa et al., 2014; Trippanera et al., 2014). Reconstructing the long-term evolution of such islands thus provide a unique opportunity to track the influence of deformation on the various stages of growth and destruction, especially through the analysis of strain and stresses recorded by the distribution of volcanic outpouts and/or the faults and dikes cutting the various edifices. Ultimately, such markers can give valuable information on the potential changes in regional strain and stress, e.g. associated with a rapid plate reconfiguration (e.g., Hildenbrand et al., 2014).

Santa Maria is the oldest island in the Azores and is situated at the intersection between the older and the current EU/NU plate boundary. Given this key position close to a plate boundary, the island is a suitable target to investigate the successive stages of construction and destruction, their possible relationships with regional tectonics, and possible changes of the stress field with time. Despite this key position and the importance of the age constraint, the geological evolution of the 
island remains not well constrained. From new morphological analyses, fieldwork, structural data, and K-Ar dating, we here constrain the volcano-tectonic evolution of Santa Maria and discuss its significance regarding regional tectonics and paleostress evolution at the western Eurasia-Nubia plate boundary.

\section{Geological background}

\section{1. Geodynamic setting}

The Azores archipelago comprises nine volcanic islands located on both sides of the MidAtlantic Rift (MAR). The islands sit on top of a large portion of elevated seafloor generally referred to as the Azores Plateau, which roughly coincides with the $-2000 \mathrm{~m}$ isobath. The genesis of the plateau, the excess of magmatism and the development of the islands have been generally attributed to the presence of an anomalous mantle under the plateau. Global and regional S-wave tomographic studies show the presence of a low seismic velocity zone between $\sim 80$ and $250 \mathrm{~km}$ depth under the whole region (for a review, see Silveira et al., 2006). This suggests that the mantle under the Azores is presently anomalously hot and/or wet. This seems consistent with the anomalous high topography of the MAR (e.g., Schilling, 1985; Escartin et al., 2001), a thicker than average crust (Searle, 1980; Detrick et al., 1995; Luis et al., 1998; Cannat et al., 1999; Gente et al., 2003; Maia et al., 2007; Silveira et al., 2010), and the geochemistry of the lavas from the islands, which overall show a strong enrichment in incompatible elements and radiogenic isotopes (e.g., Bourdon et al., 2005). MORB from the MAR close to the Azores also have relatively high $\mathrm{Sr}, \mathrm{Pb}$, and $\mathrm{He}$ isotope ratios compared to normal depleted MORB (Kurz, 1982; Schilling et al., 1983; Bourdon et al., 1996; Dosso et al., 1999; Moreira et al., 2002; Jean-Baptiste et al., 2009). However, according to other authors, the volcanism is not due to an active hot-spot, but may rather reflect the existence of volatile-enriched upper mantle domains (Schilling et al., 1975; Bonatti et al., 1990) or a wet-spot (Métrich et al., 2014). 
To the east of the MAR axis, the plateau shows a triangular shape and encompasses portions of the North American (NA), the Eurasian (EU), and the Nubian (NU) plates (Fig. 1). The NA/EU and NA/NU plate boundaries coincide with the conspicuous MAR axis, whose morphology has been relatively stable over the last few Myrs (Laughton et al., 1972). In contrast, the morphology and the history of the EU/NU boundary in the Azores are more complex. Immediately to the east of the Azores region, the EU/NU boundary presently comprises a dextral transcurrent fault called the Gloria Fault (GF). Some time in the past, the GF was connected to the MAR by an active fault called the East Azores Fracture Zone (EAFZ), bounding, in the south, the eastern Azores Plateau. However, the EAFZ seems presently seismically inactive, and thus not anymore part of the EU/NU boundary (e.g., Krause and Watkins, 1970; Searle, 1980). It is now consensual that this part of the EU/NU plate boundary has migrated to the North and is now following in part the hyper-slow oceanic Terceira Rift (TR), which bounds, in the north, the eastern Azores Plateau (e.g., Machado, 1959; Krause and Watkins, 1970; McKenzie, 1972; Searle, 1980; Vogt and Jung, 2004). A combined study of GPS, seismic and tectonic data (Marques et al., 2013a; 2014a) indicates that the EU/NU boundary presently coincides with the TR in the east but is diffuse in the west (Fig. 1). Recent morpho-structural, geodetic, geochemical and geochronological studies have shown that the volcanic construction and large-scale catastrophic destruction of Graciosa, Terceira, S. Jorge, Faial, Pico and S. Miguel islands has resulted in the development of linear volcanic ridges elongated along two main directions: $\mathrm{N} 110^{\circ}$ (mostly) and $\mathrm{N} 130^{\circ}-\mathrm{N} 150^{\circ}$ (e.g., Hildenbrand et al., 2008a; 2012a, 2012b; 2013a, 2013b; Sibrant et al., 2014; Costa et al., 2014; Trippanera et al., 2014). Such characteristics have been attributed to a significant control of volcanic outputs by regional lithospheric deformation along the current EU/NU plate boundary (e.g., Lourenço et al., 1998; Haase and Beier, 2003; Hildenbrand et al., 2008a; 2012a, 2012b; 2013a, 2013b; Navarro et al., 2009; Quartau et al., 2012; Marques et al., 2013a; 2014a; Costa et al., 2014; Trippanera et al., 2014). 
Santa Maria Island sits on the eastern edge of the Azores plateau, close to the junction between the EAFZ, the Gloria Fault and the TR. It is located in an area without current seismicity, and therefore has developped independently from the present EU/NU plate boundary. In contrast to the other Azores islands, which have all been active during the last $1.5 \mathrm{Myr}$, S. Maria has been exctinct for the last few Myr, and thus may record a story that no other island in the Azores can tell.

\section{2. Previous data on the Santa Maria Island}

From early stratigraphic studies, two main volcanic systems, separated by a volcanosedimentary complex, have been first distinguished (Agostinho, 1937). Based on fossils, Zbyszewski and Ferreira (1960) further assigned a Vindobonian age (ca. 16.4 to $7.12 \mathrm{Ma}$ ) to the volcano-sedimentary complex. However, the evolution of Santa Maria remains poorly constrained in time.

Later, Serralheiro et al. (1987) proposed a new volcanic stratigraphy, in which Santa Maria is divided into six units (Fig. 2), instead of the previous three. Two of the new units are locally known as the Porto and Cabrestantes formations. These units comprise red-altered lavas flows, which are intruded by numerous dikes, up to $5 \mathrm{~m}$ thick. These two units have very minor representation (barely visible on the geological map), and their relationships with the surrounding older volcanic complex remain unclear. The third and youngest new unit (Feteiras formation) results from the meteoric alteration of outcropping lavas, and therefore should not be considered as a distinct volcanic unit. In fact, the Feteiras formation corresponds to a thin veneer of lateritic soils (Supplementary Figure A1), which locally cover the two main volcanic complexes. It is restricted to a reduced area on the western and central parts of the island (Fig. 2). The remaining three units correspond to the previously proposed stratigraphy, with the exception of the (minor) Facho unit, which Zbyszewski and Ferreira (1960) considered to be the top of the younger volcanic complex, and Serralheiro et al. (1987) considered to be the base. Despite the new stratigraphy, the age of the main volcanic stages remained poorly constrained. 
Several studies have focussed on the age of the volcano-sedimentary complex, because it contains fossils. For example, from ${ }^{87} \mathrm{Sr} /{ }^{86} \mathrm{Sr}$ ratios measured on bivalves collected in the volcanosedimentary deposit, Kirby et al. (2007) estimated ages ranging from 10.03 to 2.24 Ma. However, based on the local magnetic field, Storetvedt et al. (1989) claimed that the younger volcanic activity shows a Gauss normal polarity (3.4 - 2.5 Ma). Whole-rock K-Ar ages acquired on the two main volcanic units range between $8.12 \pm 0.85$ and $4.13 \pm 0.35 \mathrm{Ma}$ (Abdel Monem et al., 1975), and between 5.5 \pm 1.2 Ma and 3.2 $\pm 0.17 \mathrm{Ma}$ (Féraud et al., 1981). These age determinations have been obtained on either lava flows or dikes, which are generally basaltic in composition and commonly contain olivine phenocrysts (Abdel-Monem et al., 1975; Féraud et al., 1981). All the available ages, however, have been acquired on a limited number of samples, and most of them are not precise enough to accurately constrain the volcano-tectonic evolution of Santa Maria. Furthermore, existing ages are sometimes even inconsistent, as a given unit sometimes differs by almost 3 Ma depending on the authors.

Structural information on Santa Maria Island is still relatively poor. Six interpreted faults have been recognized by Madeira, (1986) and reported in Madeira and Ribeiro (1990). They correspond to morphological lineations (inferred faults in Fig. 3), and their kinematics has been either inferred from morphological interpretation, or is not given. The kinematics reported in Madeira and Ribeiro (1990) indicates dextral strike-slip on a NNW-SSE fault, and normal kinematics on a N-S fault, which are believed to be active. A possible sinistral strike-slip on a NNESSW fault is also proposed (Madeira, 1986; Madeira and Ribeiro, 1990). From these data, Madeira and Ribeiro (1990) infer a current horizontal N-S maximum compressive stress, and an E-W least compressive stress in Santa Maria.

Numerous dikes have been observed on the island and reported on geological maps (Zbyszewski and Ferreira 1960; Serralheiro et al., 1987). They strike N045 and N150 on average. Similar directions have been also reported by Madeira (1986), but unfortunately the location of the dikes is not given, neither on a map, nor as geographic coordinates. Moreover, the significance of 
these dike trends and their geodynamic implications regarding regional tectonics remain yet enigmatic.

\section{Methods and results}

\subsection{Geomorphological analysis, fieldwork and sampling}

Our strategy was devised to constrain, in time, the main complexes of Santa Maria and their interrelationships. First, a morphological analysis of the island was performed on a DEM with a 10 $\mathrm{m}$ spatial resolution, in order to identify the main morpho-structural units and better define areas of particular importance for the subsequent fieldwork (Fig. 3). The DEM was produced from a digital topographic map of Santa Maria Island (Portuguese Army Geographic Institute, IGeoE). The full process of construction of the DEM is the same as the one used and explained in Costa et al. (2014). Then, we went around the island by boat to get a full picture of the main volcanic sequences and their first-order relationships, mostly major unconformities, faults and dikes. Fieldwork was then carried out over the whole island, through available road cuts, quarries, and accessible sea cliff exposures. We especially took advantage of the high coastal cliffs to investigate and sample the base and the top of the accessible volcanic successions. We systematically measured the attitude of the lava flows, the relationships between the various lava sequences, the position and the architecture of major unconformities, and structural elements (faults and dikes).

From the analysis of shaded relief maps, slope maps (Fig. 4), cross-sections and fieldwork, the island can be divided into two main sectors (Figs. 5, 6):

(1) The western sector is remarkably planar. It shows a regular slope gently dipping to the west $\left(<5^{\circ}\right)$, which is truncated by reduced coastal cliffs (Fig. 3, Figs. 4b, 4d). In the cliffs, the upper part of a ca. 200 m-thick succession of basaltic lava flows is exposed, and shows a general gentle dip to the WSW $\left(<10^{\circ}\right)$. Inland, a few linear canyons incise the upper part of the gentle morphological surface. These canyons show a close to $\mathrm{N} 150^{\circ}$ and $\mathrm{N} 045^{\circ}$ trend in the north and in the south, respectively. These two trends are similar to the ones interpreted as faults in previous studies 
(Madeira, 1986; Madeira and Ribeiro, 1990, Fig. 3). The western sector has been identified previously as belonging to the oldest volcanic units (e.g., Zbyszewski and Ferreira, 1960; Serralheiro et al., 1987). We note that lava flows dipping to the east have not been observed by us or by previous authors. Serralheiro et al. (1987) also noted the gentle dip to the WSW. We collected two lava flows from the base and the middle of the pile in the southern coastal cliff (samples SA12B and SA12E, respectively, Fig. 6). A lava flow from the top of this succession constitutes the flat topography near the airport (Figs. 3, 4, 6), and was also collected (sample SA12G). A few kilometres farther $\mathrm{SW}$, this succession is cut by numerous dikes oriented close to $\mathrm{N} 60^{\circ}$. These dikes are sealed in unconformity by thin lava flows (Fig. 7), which were mapped in earlier studies as the Touril complex (Serralheiro et al., 1987). These lavas were collected but, unfortunately, thin-section inspection showed that they are weathered and thus not suitable for dating. The Facho unit was mapped by Serralheiro et al. (1987) below the youngest volcanic units, which constitute most of the eastern part of the island. This seems surprising, because the whole eastern part of the island is much more eroded than the Facho edifice (Fig. 3). The latter is very well preserved, except in the central part, where the feeding system (neck) is being exploited in a large quarry. There, we sampled a lava flow (sample SA12H) associated with the neck (Fig. 6).

(2) In contrast, the eastern sector is mountainous and comprises the Pico Alto chain, which is deeply dissected by the modern hydrographical network and bounded by high coastal cliffs (Figs. 3, 4a, 4c, 4d). Several morphological characteristics can be noted. First, Pico Alto is not straight, but rather curved and concave to the east. Furthermore, it is topographically asymmetric (Fig. 4d),with a much steeper slope in the east than in the west. Both flanks are incised by deep and narrow canyons roughly perpendicular to the Pico Alto chain. The ravines cut through a sequence of thick (up to $10 \mathrm{~m}$ ), aphyric to olivine-bearing basaltic lava flows, and conglomerates. The lava flows gently dip to the WSW $\left(<10^{\circ}\right)$, similarly to the flows in the old volcanic units exposed in the west (Figs. 4, 6). The eastern part of the island is incised by 2 main deep canyons (Fig. 3), roughly elongated $\mathrm{N} 150^{\circ}$ and $\mathrm{N} 045^{\circ}$. In the east, coastal cliffs cutting the Pico Alto volcanic succession 
show a curved shape in plan view. Along the SE coast of the island, the base of the sea cliff comprises alternating marine sediments (with internal cross-bedding) and basaltic lava flows with well-preserved internal pillow structures (Fig. 8). The sediments are mostly calcarenites and include numerous marine fossils such as bivalves and some invertebrates. They are intercalated with lava flows and few hyaloclastites, which altogether have been mapped as the "Touril complex" in earlier works (Fig. 2). The marine sediments are sometimes lenticular and discontinuous, as they partly filled the irregular topography constituted locally by pillow lava structures. Just above the base of the sea cliff, a sub-horizontal thick sedimentary layer especially covers in apparent unconformity two lava flows, which have a local gentle dip toward the E despite the overall dip of the succession towards the west (Fig. 8). Three hypotheses can be considered regarding these basal flows. They may either represent the remnants of the old volcanic units, or alternatively belong to the Touril complex, as reported on the geological map, or ultimately belong to the younger volcanic units. As most lava flows in Santa Maria are basaltic, petrographic arguments are not discriminant to unambiguously conclude between the three hypotheses. The sediments themselves are covered in unconformity by a suite of thick and massive sub-aerial lava flows, which should belong to the younger volcanic units (Pico Alto) according to existing geological maps and our field observations. Therefore, we collected the freshest and more aphyric lavas below (sample SA12L) and above (sample SA12M) the sediments (Figs. 6, 8). A flow belonging to the easternmost part of the Pico Alto volcanic succession was collected close to S. Lourenço (sample SA12P, see Fig. 2 for location).

Several scoria cones more or less well-preserved are present across the entire island and referred to as belonging to the Feteiras formation (Serralheiro et al., 1987). Lava flows from several of the cones were sampled in the western, central and southeastern parts of the island (SA12O, SA12Q and SA12S respectively, Fig. 6).

\subsection{Structural analysis}


A particular attention was paid to structural markers of deformation. Faults and dike swarms, especially, may provide important information about the stress field at different times, which can be used to discuss the relationships between tectonics and volcanism at both local and regional scales, as successfully applied to other islands in the Azores (e.g., Lourenço et al., 1998; Hildenbrand et al., 2008a, 2012a; 2014; Trippanera et al., 2014).

Inland, outcrops are rare, which greatly limits the observation of faults. Therefore, we went around the island by boat to observe the cliff sections. Moreover, we could not observe the faults interpreted and reported in Madeira and Ribeiro (1990), except the one close to the airport. However, we newly recognized four main faults (Fig. 3). One of them was identified from the sea, in the SE part of Santa Maria; it shows an apparent major normal offset (Fig. 9). Unfortunately, the measurement is imprecise and without observation of striations due to the inaccessibility of the outcrop. The locations of the faults are shown in the Fig. 3. Two of the faults observed in land are close to S. Lourenço (see Fig. 2 for location). The faults are oriented $\mathrm{N} 140^{\circ}$ and $\mathrm{N} 150^{\circ}$, with a dip of ca. $80^{\circ}$ towards the SW and subvertical, respectively. These faults show striations close to dip slip, and a normal offset of 9 and $1.5 \mathrm{~m}$, respectively. Such kinematics is significantly different from the dominant dextral strike-slip behaviour proposed by Madeira and Ribeiro (1990) for the $\mathrm{N} 150^{\circ}$ faults.

We also observed a major fault close to the Airport, with a $\mathrm{N} 045^{\circ}$ trend and a minimum offset of $10 \mathrm{~m}$. Striations could be measured plunging $75^{\circ}$ to the $\mathrm{SW}$, which together with displaced markers indicate a dominant normal component with minor dextral strike-slip component. We note that (seemingly) the same fault is reported in Madeira and Ribeiro (1990) and marked by a dashed line, however with a sinistral component of strike-slip.

We observed and measured about 30 dikes across the island (Table 1). They are reported in Fig. 3, along with those mapped by Zbyszewski and Ferreira (1960). Stereo-plots additionally combine our dikes measurements with the data from Madeira (1986). Although the location of his measurements is not given, Madeira (1986) distinguished dikes from the western and eastern 
sectors of the island. We followed the same distinction, and show them with distinct colours. Two major populations of dikes are recognized, as schematically represented on the simplified structural map shown in Fig. 3:

- A ca. NE-SW $\left(\mathrm{N} 045^{\circ}\right)$ trend is localized mainly in the western part of Santa Maria, and much more on the southern than on the northern part of the island. The dikes are truncated by a regular erosional surface (Fig. 7), and covered, in angular unconformity, by thin lava flows of the unit that has been mapped as the Touril Complex (Fig. 2). A few dikes closer to $\mathrm{N}-\mathrm{S}$ have also been measured in this sector.

- A ca. NNW-SSE $\left(\mathrm{N} 150^{\circ}\right)$ trend is mainly measured in the eastern sector, especially along the Pico Alto axis. Despite the main $\mathrm{N} 150^{\circ}$ direction, the dikes in this sector show a slightly curved distribution in plan view (concave eastward), gradually changing from NNW-SSE in the south to NNE-SSW in the north. This curved trend is similar to the distribution of late parasitic cones further to the east (Fig. 3).

\subsection{K-Ar dating on separated groundmass}

We systematically collected fresh lava flows with no visible traces of alteration. All the samples were carefully observed in thin-section to ensure the freshness of the rocks. Santa Maria rocks are primary basalts with phenocrysts of olivine, pyroxene and/or plagioclase in various proportions. Based on the micro-textural characteristics, the samples were crushed and sieved to a 125-250 micrometre size fraction and ultrasonically cleaned for $10 \mathrm{~min}$ in dilute nitric acid solution. To avoid weathered material as well as excess argon potentially carried by the phenocrysts, the freshest part of the groundmass was separated, within a narrow density interval, with heavy liquids and a magnetic separator. $\mathrm{K}$ and Ar were measured in Laboratory GEOPS (Orsay, France) on the homogeneous preparation of the groundmass by flame spectrometry and mass spectrometry, respectively. $\mathrm{K}$ was released from the groundmass during an acid attack, and the sample solution was measured and compared with the one obtained on BCR-2 and MDO-G geostandards. K was 
determined with a $1 \%$ uncertainty (Gillot et al., 1992). Ar was measured with the unspiked K-Ar Cassignol-Gillot technique (Cassignol and Gillot, 1982), with a mass spectrometer similar to the one described in Gillot and Cornette (1986). The unspiked Cassignol-Gillot has been shown especially suitable to date precisely young volcanic rocks, even basic in composition (e.g., Gillot et al., 2006; Al Kwatli et al., 2012; Boulesteix et al., 2012; 2013). The standards GLO and HDB-1 were used for ${ }^{40} \mathrm{Ar}$ signal calibration. Typical uncertainties of $1 \%$ are achieved for the ${ }^{40} \mathrm{Ar}$ signal calibration. The uncertainty on the correction of atmospheric contamination is a function of the radiogenic content of the sample $\left({ }^{40} \mathrm{Ar} *\right)$. It rapidly vanishes and becomes negligible for ${ }^{40} \mathrm{Ar}^{*}$ exceeding $10 \%$. The detection limit for 40Ar* is presently $0.1 \%$ (Quidelleur et al., 2001; Gillot et al., 2006). Decay constants and isotopic ratios of Steiger and Jager (1977) were used. K and Ar measurements were duplicated for each sample. The age uncertainties are given at $1 \sigma$.

The new ages range between 5.70 $\pm 0.08 \mathrm{Ma}$ and $2.84 \pm 0.04 \mathrm{Ma}$ (Fig. 6 and Table 2). They are fully consistent with the stratigraphic control of Zbyszewski and Ferreira (1960) and ours, and provide new important insight into the geological evolution of Santa Maria. The volcanic succession exposed in the western cliffs of the island is here dated between $5.70 \pm 0.08$ and $5.33 \pm$ 0.08 Ma. This is compatible with a previous age of $5.27 \pm 0.15 \mathrm{Ma}$ obtained by Féraud et al. (1981) on the same unit, but much younger than the value of $8.12 \pm 0.85$ Ma measured by Abdel Monem et al. (1975). The most plausible explanation for such a large difference is that the older age measured by Abdel-Monem et al. (1975) on whole rock is significantly biased by the unsuitable incorporation of phenocrysts and/or weathered phases. The lava flows sampled below and above the thick sedimentary layer at the base of the SE coastal cliff are here dated at $4.32 \pm 0.06 \mathrm{Ma}$ (SA12L) and $4.02 \pm 0.06 \mathrm{Ma}(\mathrm{SA} 12 \mathrm{M})$, respectively. The thick lava flows collected in the middle and upper parts of the eastern volcanic succession attributed to Pico Alto (Zbyszewski and Ferreira, 1960; Serralheiro et al., 1987) yield new ages of $3.96 \pm 0.06$ and $3.94 \pm 0.06 \mathrm{Ma}$ (samples SA12N and SA12P, respectively). We note that these two ages are undistinguishable, within the range of uncertainties, from the age obtained on our sample SA12M (collected above the thick sedimentary 
layer at the base of the SE coastal cliff). Lava flows from scoria cones sampled in the eastern part of the island (SA12Q and SA12S) yield undistinguishable ages of $3.60 \pm 0.05$ and $3.52 \pm 0.05$ Ma. Finally, the Facho volcanic unit is here dated at $2.84 \pm 0.04 \mathrm{Ma}$. This is much younger than any age previously reported, thus extending the volcanic activity on Santa Maria down to less than $3 \mathrm{Ma}$ ago. The new age here obtained also confirms that the Facho volcanic cone overlies the second main volcanic complex, as deduced from our field observations (Fig. 5), and thus supports the stratigraphic analysis of Zbyszewski and Ferreira (1960).

\section{Discussion}

\subsection{Calibration of the island stratigraphy}

Our data are consistent with our field observations, mostly based on major unconformities, and overall consistent with the main geological units previously described by others, especially Zbyszewski and Ferreira (1960) (Fig. 6). However, we here provide new important temporal constraints, which allow us to revise significantly the age of the main units. For the sake of simplicity, we will use stratigraphy-related names, and recognize, from older to younger (Figs. 5, 6): (1) the Older Shield Volcano (locally known as the Anjos Complex), which consists of successions of thin lava flows of basalts and some intermediate rocks, with a gentle dip to the W of $10^{\circ}$ or less (like in a shield volcano). From our data, it was active until at least 5.3 Ma. (2) The Intermediate Volcano-Sedimentary Complex (locally known as the Touril Complex), which is stratigraphically in an intermediate position, between the older and younger volcanic complexes. It comprises pillow lavas, hyaloclastites, calcarenites, conglomerates, sandstones and some subaerial lavas. (3) The Younger Shield Volcano (locally known as the Pico Alto Complex), which makes up the whole eastern half of the island and is here dated up to at least 3.9 Ma. It comprises basaltic lava flows and dikes. (4) Finally, late volcanic cones emplaced over the eroded remnants of all previous

units, and here dated between 3.6 Ma and 2.84 Ma. We coin this late phase the Later Parasitic Activity (locally known as the Feteiras Formation). In summary, we distinguish two main shield 
volcanoes separated by an intermediate volcano-sedimentary complex.

In the framework of this stratigraphy, the meaning of the ages obtained on our samples SA12L and SA12M collected below and above the marine sediments on the SE coast (Fig. 8) needs to be carefully discussed. The value of $4.32 \pm 0.06 \mathrm{Ma}$ obtained on SA12L (the lava below the sediments), especially, is about $1 \mathrm{Myr}$ younger than the age of $5.33 \pm 0.08 \mathrm{Ma}$ measured on the lava flow sampled at the (local) top of the Older Volcano succession near the airport (our sample SA12G). The current topography on top of this western succession is gently sloping to the west, and can therefore be interpreted in two different ways: (1) a structural surface, i.e. the present topography is approximately following the initial dip of the lava flows; or (2) a platform created by marine abrasion, as observed on other volcanic islands, e.g., in the Tyrrhenian Sea (e.g., Aiello et al., 2007), on Sal Island in the Cape Verde archipelago (e.g., Zazo et al., 2006), or on Tenerife in the Canary Islands (e.g., Ablay and Hürlimann 2000; Kröchert et al., 2008). The second hypothesis seems the most plausible because some lava flows conceal in unconformity the Older Shield Volcano lavas in the southwestern sector (Figs. 6, 8). This means that the late activity of the Older Shield Volcano most probably ended after 5.3 Ma ago. However, the original dip of the old lava flows is very gentle, so marine erosion may not have removed a significant part of the Older Shield Volcano succession. Consequently, it seems unlikely that the missing part would cover a period as long as $1 \mathrm{Myr}$ (between 5.3 and 4.3 Ma). Therefore, the lava here dated at 4.32 $\pm 0.06 \mathrm{Ma}$ (our sample SA12L) most likely does not belong to the Older Shield Volcano. Alternatively, the lava flows under the sediments most likely represent one of the several submarine lava flows (with some pillow lavas), from the Intermediate Volcano-Sedimentary Complex. Similar alternations of pillow lavas, sedimentary layers and sub-aerial lavas in volcano-sedimentary successions have been described for instance in Hawaii and Tenerife islands (e.g., Leslie et al., 2004; Kröchert et al., 2008, respectively). The overall small difference between the ages here obtained on the two lava flows bracketing the sediments, and with subsequent lava flows up to the top of the Pico Alto Chain, supports a rather rapid construction of a volcano, first in a shallow submarine environment and then 
under sub-aerial conditions. In other words, the part of the Intermediate Volcano-Sedimentary Complex exposed in the SE sector most probably reflects the early emerging part of the Younger Shield Volcano. This is consistent with what is observed along the eastern cliff of the island. Unlike the western sector, where the old succession is apparently composed of sub-aerial volcanic deposits (scoriae deposits, lava flows altered under oxidising conditions, presence of palaeosoils, and, mostly, absence of pillow lavas), the base of the eastern coastal cliffs is dominantly constituted by alternating marine sediments, pillow-lavas and/or hyaloclastites, exposed up to $20 \mathrm{~m}$ above current sea level.

\subsection{Volcano-tectonic evolution of Santa Maria}

According to our new data, the evolution of Santa Maria involved the construction and partial destruction of two main volcanoes, the Older and the Younger Shield volcanoes, which have been active from 5.7 Ma to less than 5.3 Ma, and between 4.32 and 3.94 Ma, respectively (Figs. 3, 7, 8, 9). The later eruption (Facho volcano) is here dated at 2.84 Ma.

From the gentle westward dip of lava flows in both Older and Younger Shield volcanoes, we infer that they were originally shield volcanoes, whose summits, eastern flanks, and part of the western flanks do not exist anymore. The distribution and geometry of the three main Santa Maria units show that only a part of them is presently preserved. The western flank of the Younger Shield Volcano, especially, is nested within a topography cutting the eastern flank of the Old Shield Volcano. This topography can be the result of (1) marine and/or stream erosion, (2) pure tectonic displacements, or (3) lateral flank collapses:

(1) Erosion can be relatively efficient and destroy a significant part of oceanic islands over rather short geological periods, especially under tropical climate (e.g., Hildenbrand et al., 2008b; Samper et al., 2009; Germa et al., 201, 2011; Lahitte et al., 2012; Salvany et al., 2012; Ricci et al., 2014). However, regular stream erosion generally produces the development of canyons and valleys, but alone does not remove in an asymmetric way the whole flank of a volcano and its 
summit.

(2) The existence of a major fault between the two main volcanoes cannot be excluded, although not observed in the field. Several faults have been measured in this study, but the vertical offset generally does not exceed a few meters or at most a few tens of meters, which does not seem sufficient to account for the present lateral contact between the two volcanoes, and for the gradual displacement of the eastern flank of the Younger Shield Volcano. Furthermore, the Intermediate Complex apparently lies on a surface with a gentle dip to the East, rather than on a surface with a steep geometry, such as a normal fault scarp.

(3) Therefore, the alternative is that the eastern flank of both volcanoes has been removed by a large-scale catastrophic event, in the form of a giant sector collapse as suggested by Marques et al. (2013b). The first sector collapse towards the east (Fig. 10B) left a scar that comprises the east dipping unconformity on top of which the Intermediate Volcano-Sedimentary Complex was deposited. Unfortunately, the scar could not be observed despite the boat trip around the island, but a steeper scar could well be present under the sea level.

Partial destruction of an edifice is usually followed by an eruptive response, and thus influences the magma plumbing system as observed in Hawaii (e.g., Presley et al., 1997), the Canary (Longpré et al., 2010; Boulesteix et al., 2012), in Polynesia (e.g., Clouard et al., 2001; Clouard and Bonneville, 2004; Hildenbrand et al., 2004; 2008b), and also in continental areas as in the Andean Central volcanic zone (Hora et al., 2007). Here, we propose that such sector collapse likely changed the stress field in the earlier volcanic edifice as observed at Mount Etna (Italy), where the volcanic conduit migrated after a moderate slide (e.g., Nicolosi et al., 2014). The major flank collapse here proposed in Santa Maria probably influenced the magma plumbing system of the island leading to the fast growth of the Young Shield Volcano in the landslide scar (Fig. 10C). Such rapid eruptive response to giant landslides has been extensively recognized in other oceanic islands worldwide (e.g., Lipman et al., 1988; Watts and Masson, 2001; Gillot et al., 1994; Hildenbrand et al., 2004; 2006; Quidelleur et al., 2008; Boulesteix et al., 2012; 2013). Quidelleur et 
al. (2008) proposed that dating the base of the post-collapse volcanism provides the best constraint on the age of a given large sector collapse. Based on such considerations, the first flank collapse in Santa Maria would have happened soon before 4.3 Ma.

In Santa Maria, at least the eastern flank and the summit of the Younger Shield Volcano are also missing. The current steep and curved topography in the east mimics a horseshoe shape depression, which could therefore represent the remnants of the scar of a second major flank collapse (Fig. 10D). The inferred scar of the second sector collapse is greatly degraded, and most likely rooted in the nearby sea, but the distribution of later (ca. $3.56 \mathrm{Ma}$ ) parasitic cones and a part of the dikes along an arc concave to the east in the easternmost part of Santa Maria could have been triggered by the sector collapse through depressurization of the main feeding system (e.g., Manconi et al., 2009; Pinel and Albino, 2013). Therefore, at least two major faults should exist: one that affected the Older Shield Volcano and occurred before the construction of the Younger Shield Volcano (i.e. between ca. 5.33 and $4.32 \mathrm{Ma}$, and probably soon before $4.3 \mathrm{Ma}$ ), and another that affected the Younger Shield Volcano, and thus occurred after 3.94 Ma and before ca. 3.6 Ma. The one most to the west could not be found yet, because the fault has been most likely covered by the Younger Shield Volcano, and is below sea level. In contrast, a fault displacing the Younger Shield Volcano succession can be observed most to the east on the sea cliff (Fig. 9). It may represent one of the faults branching under the sea on the main fault of the second sector collapse. Two other faults have been observed close to S. Lourenço (see Fig. 2 for location). Oriented along a N160 and $\mathrm{N} 140^{\circ}$ trend, they indicate a normal fault displacement (Fig. 3). These orientations and kinematics are coherent with the direction of a probable flank collapse towards the E. Unloading of the volcanic edifice and associated decompression of the magma feeding system was likely responsible for the emplacement of part of the dikes and volcanic cones along the arcuate scar, concave to the east, between $3.60 \pm 0.05$ and $3.52 \pm 0.05 \mathrm{Ma}$, which suggests that the second flank collapse may have occurred between 3.94 and 3.6 Ma. From the new ages here reported, the volcanic activity in Santa Maria lasted until at least 2.84 \pm 0.04 Ma ago (Figs. 6, 10). 


\subsection{Lithospheric control of volcanism}

The construction of Santa Maria at the SE edge of the Azores plateau has been interpreted by some authors as reflecting the older activity of the "Azores plume" (e.g., Beier et al., 2013). However, our new ages indicate that the sub-aerial volcanic activity in Santa Maria occurred at the same location during a period of ca. 3 Myr. The half-spreading rate at the MAR is presently ca. 11 mm/yr (DeMets et al., 2010), so relative plate movement over an eventual stationary plume would have resulted in a drift of the volcanism by ca. $33 \mathrm{~km}$ toward the west, which is the opposite of what we measured in Santa Maria: older volcanics in the west (> ca. 5.3 Ma), and younger volcanics in the east (< ca. $4.3 \mathrm{Ma})$. On the other hand, the absolute motion of both Nubia and Eurasia plates towards the SW at a mean rate of $2 \mathrm{~cm} / \mathrm{yr}$ (Gripp and Gordon, 2002), over a plume fixed in the absolute reference frame, would have resulted in a migration of volcanism of ca. $70 \mathrm{~km}$ towards the NE. However, this magnitude of displacement is not observed in Santa Maria. Moreover, both $33 \mathrm{~km}$ and $70 \mathrm{~km}$ migrations are smaller than the lithospheric thickness (Silveira et al., 2010), and might therefore be filtered by lithospheric processes rather than by asthenospheric processes. Such effect of the lithosphere structure on the melt extraction can be partly controlled by the rate of extension, the internal kinematics of the thick lithosphere (e.g., England, 1983; PerezGusinnye et al., 2006), the rheology of the lithosphere (e.g., Huismans and Beaumount, 2011; Martinod and Davy, 1992), the thickness ratio between the crust and the lithospheric mantle (e.g., Hopper and Buck, 1996), the existence of previous discontinuities and lithospheric heterogeneities (e.g., Petit and Deverchere, 2006). This suggests that the magma upwelling under Santa Maria has been persistently focussed along main lithospheric fractures, and therefore that Santa Maria's evolution and dike emplacement has been greatly influenced by regional deformation.

Dikes are good indicators of the paleo-stress field, and there are several previously conducted studies on the reconstruction of stress fields in volcanic regions using the distribution and geometry of intrusions (O’de, 1957; Muller and Pollard, 1977; Nakamura, 1977). The local 
stress field around a magma reservoir show radial dikes configuration and is controlled by the depth, shape, and internal excess pressure of the reservoir (Chadwick and Dieterich, 1995; Gudmundsson, 1998; Roman and Jaupart, 2014). The dikes can also show a cone sheet or ring circumferential geometry, which indicate inflation or deflation of a magma chamber (Nakamura, 1977). The propagation pattern of the intrusions in the vicinity of the reservoir reflects the local stress field formed by the magma reservoir, while the structural development of intrusions during volcanic activity records the tectonic evolution of the magma system beneath or inside the volcano (Geshi et al., 2012). Nevertheless, when the distribution of dikes in an individual volcano is linear (or rectilinear) instead of radial, and hence despite the geometry of the volcano, they can be considered as a marker of tectonic stress and/or re-activation of inherited geological structures in the regional stress field (Nakamura, 1977; Tibaldi et al., 2014 and references therein).

The distribution of the two dike swarms in the Older and Younger Shield volcanoes of Santa Maria is not radial to the volcanic edifice. As the eastern part of the Younger shield Volcano is presently missing, the initial eruptive centre had to be located east of the island. For a hypothetical radial distribution, dikes would gradually birfucate and range in strike between NE-SW in the S, to closer to NW-SE in the N. Such distribution is not observed in both volcanoes, in fact the observed distribution is at $90^{\circ}$ to the expected in a radial distribution. Therefore, dike emplacement in Santa Maria does not seem to be directly linked to local shallow stresses, e.g. due to inflation of the edifice over a magma chamber (Nakamura, 1977; Fiske and Jackson, 1975; Takada, 1999). Moreover, the majority of the rocks in Santa Maria are basalts, basanites to picrobasalts, with a $\mathrm{K}_{2} \mathrm{O}$ content of less than $2.5 \mathrm{wt} \%$ (Beier et al. (2013). Thus, the overall basic composition of the lavas erupted on Santa Maria does not support the existence of a large magmatic chamber underneath the island (e.g., Beier et al., 2013), which would promote differentiation.

The $\mathrm{N} 150^{\circ}$ trend has been mapped in other islands in the Azores and is a currently active structural trend (e.g., Féraud et al., 1980; Hildenbrand et al., 2008a; Hipólito et al., 2011; Silva et al., 2012). Therefore, it seems reasonable to assume that the $\mathrm{N} 150^{\circ}$ dike swarm mapped in Santa 
Maria records, to a first approximation, the regional stress field (Fig. 3). This structural trend represents also the orientation of the canyons which have been interpreted as the surface expression of faults by Madeira and Ribeiro (1990). From our few measurements of fault kinematics, it appears that the NE-SW extension is coherent with the average $\mathrm{N} 150^{\circ}$ dike trend. If the dikes in Santa Maria effectively result from magma intrusion in fractures roughly orthogonal to the least compressive stress, then the stress field changed when dike intrusion changed in orientation from $\mathrm{N} 045^{\circ}$ to $\mathrm{N} 150^{\circ}$.

The $\mathrm{N} 045^{\circ}$ and $\mathrm{N} 150^{\circ}$ dike trends are found in the Olderr and Younger Shield volcanoes, respectively. As the $\mathrm{N} 045^{\circ}$ swarm does not intrude the Younger Shield Volcano and the lava flows unconformably covering the old volcanic succession (Fig. 7), we can reasonably infer that it fed the late activity of the Older Shield Volcano, and thus was active between 5.3 Ma and 4.3 Ma. In turn, the younger $\mathrm{N} 150^{\circ}$ dikes intrude mostly the Younger Shield Volcano and in a minor part the Older Shield Volcano. This indicates that the $\mathrm{N} 150^{\circ}$ trend is younger than $4.3 \mathrm{Ma}$ and occured during the building of the Younger Shield Volcano. This suggests that the two main phases of volcanic growth on Santa Maria record a major tectonic change, which occurred between 5.3 and 4.3 Ma. According to DeMets et al. (2010), the NU/EU relative motion trends approximately N060, which means that the $\mathrm{N} 150^{\circ}$ faults are orthogonal to extension and thus prone for magma intrusion. Luís et al. (1994), based on the analysis of an aeromagnetic survey of the Azores, recognized a plate reconfiguration between anomalies 4 and 3A time (i.e. between 8.69 and $3.85 \mathrm{Ma}$ ), which is consistent with our new data and interpretation.

We note that a $\mathrm{N} 150^{\circ}$ trending dike swarm has also been found in the oldest part of S. Jorge Island (Hildenbrand et al., 2008a). From a palaeomagnetic study, Silva et al. (2012) obtained a reversed polarity on the $\mathrm{N} 150^{\circ}$ dikes of SE S. Jorge, which, together with the ages measured by Hildenbrand et al. (2008a), constrains dike emplacement in S. Jorge between ca. 1.32 and 0.79 Ma. Hildenbrand et al. (2008a) also showed that the $\mathrm{N} 150^{\circ}$ dike system in S. Jorge was followed by a new dike system striking $\mathrm{N} 110^{\circ}$, which is consistent with the direction of construction of the linear 
volcanic ridges in the Central Azores during the last $0.79 \mathrm{Myr}$. The N110 direction has not been found in Santa Maria. However, the $\mathrm{N} 045^{\circ}$ trend of the dikes and the kinematic given by the N045 fault are fully consistent. The kinematic indicates a NW-SE extension with a small dextral strike-

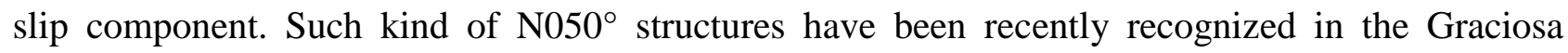
Island (Sibrant et al., 2014) and close to Faial Island (Marques et al., 2014b). The trend is predicted by plate velocities calculated by DeMets et al. (2010), and in the fault solutions of earthquakes (e.g., Borges et al., 2007; Marques et al., 2014b). As suggested by Marques et al. (2014b), the N050 direction work as a dextral strike-slip fault, similar to the Gloria fault as expected from the counter clockwise rotation of NU relative to EU (DeMets et al., 2010). According to DeMets et al. (2010) and Marques et al. (2014b), the N050 faults can accommodate the change in strike of the TR. By analogy, the two main dike swarms recognized in Santa Maria may reflect a change in palaeostress in the Azores between 5.33 and 4.32 Ma. Moreover, the $\mathrm{N} 050^{\circ}$ is parallel to the local direction of the EAFZ, and the $\mathrm{N} 150^{\circ}$ is parallel to the local trend of the TR SE of S. Miguel (Fig. 1). Therefore, it is most likely that the evolution of S. Maria records the activity of a regional structure similar to the current TR, which from our new geochronological data would have been active between at least 5.7 and 2.8 Ma.

Finally, because some dikes seem to follow the direction of the Pico Alto Chain, and because the direction of the landslides are coherent with the local extension deduced from dikes, we suggest that the major tectonic reorganization could have favoured the localization and the triggering of the major flank instabilities here proposed.

\section{Conclusions}

From morphologic, stratigraphic, tectonic and new high-precision K-Ar data, we constrain the volcanic activity of Santa Maria between ca. 5.7 and 2.8 Ma. The history of Santa Maria is marked by two phases of fast volcanic growth (5.7 to $5.3 \mathrm{Ma}$, and 4.3 to $3.9 \mathrm{Ma}$ ), with the construction of two large shield volcanoes, separated by a large-scale flank collapse between $5.33 \pm$ 
$0.08 \mathrm{Ma}$ and $4.32 \pm 0.06 \mathrm{Ma}$. A second sector collapse occurred around 3.60 Ma, which removed a great part of Santa Maria. The most recent volcanic activity in Santa Maria is represented by Parasitic Scoria Cones unconformably sitting on top of the Younger Shield Volcano, up to at least $2.8 \mathrm{Ma}$ ago.

From the strike of dikes and the age of the lavas intruded by the dikes, we identify an older N045 ${ }^{\circ}$ system (< ca. $5.3 \mathrm{Ma}$ ), and a younger N150 system (< ca. $4.3 \mathrm{Ma}$ ), from which we propose that the stress field changed between ca. $5.3-4.3 \mathrm{Ma}$. The N045 ${ }^{\circ}$ trend, also recognized in the nearby S. Miguel Island, may materialize major lithospheric discontinuities associated with the development of lithospheric structures after the end of the activity in the East Azores Fracture Zone. Therefore, the sudden jump in dike swarms direction here evidenced on S. Maria may reflect a major tectonic change accompanying the reconfiguration of the EU/NU boundary in the area between the EAFZ and the TR.

\section{ACKNOWLEDGMENTS}

We thank K. Nemeth and an anonymous Reviewer for their constructive remarks, which helped to significantly improve the paper. This study was mostly supported by research project MEGAHazards (PTDC/CTE-GIX/108149/2008) funded by FCT (Portugal). ACG Costa benefitted from a PhD scholarship (SFRH/BD/68983/2010), FCT (Portugal). The authors wish to thank V.

Godard for preparing thin sections. We acknowledge A. Davaille for her critical reading of the manuscript. This is LGMT contribution 121. 


\section{REFERENCES CITED}

Abdel Monem, A.A., Fernandez, L.A., Boone, G.M., 1975. K-Ar ages from the Eastern Azores Group (Santa Maria, São Miguel, Formigas islands). Lithos 8, 247-254.

Ablay, G., Hürlimann, M., 2000. Evolution of the north flank of Tenerife by recurrent giant landslides. J. Volc. Geotherm. Res. 103 (1-4), 135-159.

Agostinho, J., 1937. Sobre a tectónica da Ilha de Santa Maria. Açoreana 1, 281-286.

Aiello, G., Barra, D., DePippo, T., Donadio, C., Petrosino, C., 2007. Geomorphological evolution of Phlegrean volcanic islands near Naples, Southern Italy. Z. Geomorph. N. F. 51 (2), 165-190.

Al Kwatli, M.A., Gillot, P.Y., Zeyen, H., Hildenbrand, A., Al Gharib, I., 2012. Volcano-tectonic evolution of the northern part of the Arabian plate in the light of the new K-Ar ages and remote sensing: Harrat Ash Shaam volcanic province (Syria). Tectonophysics 580, 192-207.

Ancochea, E., Huertas, M.J., Hernan, F., Brändle, J.L., 2010. Volcanic evolution of São Vicente, Cape Verde Islands: the Praia Grande landslide. J. Volc. Geotherm. Res 198 (1-2), 143-157.

Beier, C., Mta, J., Stöckhert, F., Mattielli, N., Brandl, P.A., Madureira, P., Genske, F.S., Martins, S., Madeira, J., Haase, K.M., 2013. Geochemical evidence for melting of carbonated peridotite on Santa Maria Island, Azores. Contrib. Mineral Petrol. 165, 823-841.

Bonatti, E., 1990. Not so hot "hot spots" in the oceanic mantle. Science, 250, 107-111.

Borges, J.F., Bezzeghoud, M., Buforn, E., Pro, C., Fitas, A., 2007. The 18980, 1997 and 1998 Azores earthquakes and some seismo-tectonic implications. Tectonophysics 435, 37-54.

Bouleisteix, T., Hildenbrand, A., Soler, V., Gillot, P.Y., 2012. Eruptive response of oceanic islands to giant landslides: new insights from the geomorphologic evolution of the Teide-Pico Viejo volcanic complex (Tenerife, Canary). Geomorphology 138 (1), 61-73.

Bouleisteix, T., Hildenbrand, A., Soler, V., Quidelleur, X., Gillot, P-Y., 2013. Coeval giant landslides in the Canary Islands: Implications for global, regional and local triggers of giant flank collapses on oceanic volcanoes. J. Volc. Geotherm. Res. 257 (1), 90-98. 
Bourdon, B., Zindler, A., Elliott, T., Langmuir, C.H., 1996. Constraints on the mantle melting at mid-ocean ridges from global ${ }^{238} \mathrm{Ur}^{230} \mathrm{Th}$ disequilibria data. Nature 384, 231-235.

Bourdon, B., Turner, S.P., Ribe, N.M., 2005. Partial melting and upwelling rates beneath the Azores from a U-series isotope perspective. Earth Planet. Sci. Lett. 239, 42-56.

Calvert, A.T., Moore, R.B., McGeehin, J.P., Rodrigues da Silva, A.M., 2006. Volcanic history and 40Ar/39Ar and 14C geochronology of Terceira Island, Azores, Portugal. J. Volc. Geotherm. Res. 156, 103-115.

Cannat, M., Briais, A., Deplus, C., Escartin, J., Georgen, J., Lin, J., Mercouriev, S., Meyzen, C., Muller, M., Pouliquen, G., Rabain, A., Da Silva, P., 1999. Mid Atlantic rige Azores hotspot interactions: along axis migration of a hotspot derived event of enhanced magmatism 10 to 4 Ma ago. Earth Planet. Sci. Lett. 173 (3), 257-269.

Carracedo, J.C., 1994. The Canary Islands: an example of structural control on the growth of large oceanic-island volcanoes. J. Volc. Geotherm. Res. 60, 225-241.

Carracedo, J.C., Day, S.J., Guillou, H., 1999. Quaternary collapse structures and the evolution of the western Canaries (Las Palmas and Hierro). J. Volc. Geotherm. Res. 94, 169-190.

Cassignol, C., Gillot, P.Y., 1982. Range and effectiveness of unspiked potassium-argon dating: Experimental groundwork and applications. John Wiley, New York, 159-179.

Chadwick, W.W., Dieterich, J.H., 1995. Mechanical modeling of circumferential and radial dike intrusion on Galapagoes volcanoes. J. Volc. Geotherm. Res. 66, 37-52.

Chovelon, P., 1982. Evolution volcano-tectonique des îles de Faial et Pico. Thèse, faculté des sciences de la Terre, Université Paris Sud 11, 242pp.

Clouard, V., Bonneville, A., Gillot, P.Y., 2001. A giant landslide on the southern flank of Tahiti Island, Frenc Polynesia. Geophys. Res. Lett., 28 , 2253-2256.

Clouard, V., Bonneville, A., 2004. Submarine Landslides in French Polynesia, In Oceanic Hotspots : intraplate submarine magmatism and tectonism, Eds R. Hekinian, P. Stoffers and J.-L. Cheminé, Springer-Verlag,pp 209-238. 
Costa, A.C.G., Marques, F.O., Hildenbrand, A. Sibrant, A.L.R., Catita, C.M.S., 2014. Large scale flank collapse in steep volcanic ridge: Pico-Faial Ridge, Azores Triple Junction. J. Volc. Geotherm. Res. 272, 111-125.

DeMets, C., Gordon, R., Argus, D.F., 2010. Geologically current plate motions. Geophys. J. Int. $181,1-80$.

Detrick, R.S., Needham, H.D., Renard, V., 1995. Gravity anomalies and crustal thickness variations along the Mid-Atlantic Ridge between $33^{\circ} \mathrm{N}$ and $40^{\circ} \mathrm{N}$. J. Geophys. Res. 100, 3767-3787.

Dosso, L., Bougault, H., Langmuir, C., Bollinger, C., Bonnier, O., Etoubleau, J., 1999. The age and distribution of mantle heterogeneity along the Mid-Atlantic Ridge (31-41 degrees N). Earth Planet. Sci. Lett. 170, 269-286.

England, P.C., 1983. Constraints on extension of continental lithosphere. J. Geophys. Res. 88, 1145-1152.

Escartin, J., Cannat, M., Pouliquen, G., Rabain, A., Lin, J., 2001. Constraints on the interaction between the Mid-Atlantic Ridge and the Azores hotspot from bathymetry and gravity (36-39N). J. Geophys.Res. 106, 21719-21736.

Féraud, G., Kaneoka, S., Allègre, C., 1980. K/Ar ages and stress pattern in the Azores: Geodynamic implications. Earth Planet. Sci. Lett. 46, 275-286.

Féraud, G., Schmincke, H.U., Lietz, J., Gastaud, J., Pritchard, G., Bleil, U., 1981. New K-Ar Ages, Chemical Analyses and Magnetic Data of Rocks from the Islands of Santa Maria (Azores), Porto Santo and Madeira (Madeira Archipelago) and Gran Canaria (Canary Islands). Bull. Volcanol. 44, 359-357.

Fiske, R.S., Jackson, E.D., 1975. Orientation and growth of Hawaiian rifts: The effect of regional structure and gravitational stresses. Proc. Roy. Soc. London, 329, 299-326.

Gente, P., Dyment, J., Maia, M., Goslin, J., 2003. Interaction between the Mid Atlantic ridge and the Azores hotspot during the last 85 Myr: Emplacement and rifting of the hotspot derived plateaus. Geochem. Geophys. Geosyst. 8, Q03013, doi:10.1029/2006GC001318. 
Germa, A., Quidelleur, X., Labanieh, S., Lahitte P., Chauvel, C., 2010. The eruptive history of Morne Jacob volcano (Martinique Island, French West Indies): geochnology, geomorphology and geochemistry of the earliest volcanism in the recent Lesser Antilles arc. J. Volc. Geotherm. Res. 198, 297-310.

Germa, A., Quidelleur, X., Labanieh, S., Chauvel, C., Lahitte, P., 2011. The volcanic evolution of Martinique Island: insights for the Lesser Antilles arc migration since the Oligocene. J. Volc. Geotherm. Res. 208, 122-135.

Geshi, N., Kusumoto, S., Gudmundsson, A., 2012. Effects of mechanical layering of horst rocks on dike growth and arrest. J. Volc. Geotherm. Res. 223-224, 74-82.

Gillot, P.Y., Cornette, Y., 1986. The Cassignol technique for potassium-argon dating, precision and accuracy: examples from late Pleistocene to recent volcanics from southern Italy. Chem. Geol. $59,205-222$.

Gillot, P.Y., Cornette, Y., Max, N., Floris, B., 1992. Two reference materials, trachytes MDO-G and ISH-G, for argon dating K/Ar and 40Ar/39Ar datnig of Pleistocene and Holocene rocks. Geostand. Geoanal. Res. 16, 55-60.

Gillot, P.Y., Lefèvre J.C., Nativel, P.E., 1994. Model for the structural evolution of the volcanoes of Reunion Island. Earth Planet. Sci. Lett. 122 (3-4), 291-302, doi:10.1016/0012$821 X(94) 90003-5$.

Gillot, P.Y., Hildenbrand, A., Lefèvre, JC., Albore-Livadie, C., 2006. The K/Ar dating method: Principle, analytical techniques, and application to Holocene volcanic eruptions in the southern Italy. Acta Vulcanologica 18, 55-66.

Gudmundsson, A., 1998. Magma chambers modelled as cavities explain the formation of rift zone central volcanoes and their eruption and intrusion statitics. J. Geophys. Res. 103, 7401-7412.

Gripp, A.E., Gordon, R.G., 2002. Young tracks of hotspots and current plate velocities. Geophys. J. Int. 150, 321-361. 
Haase, K.M., Beier, C., 2003. Tectonic control of ocean island basalt sources on São Miguel, Azores? Geophys. Res. Lett. 30, doi:10.1029/2003GL017500.

Hildenbrand, A., Gillot, P.Y., Le Roy, I., 2004. Volcano-tectonic and geochemical evolution of an oceanic intra-plate volcano: Tahiti-Nui (French Polynesia). Earth Planet. Sci. Lett. 217 (3), 349-365.

Hildenbrand, A., Gillot, P.Y., Bonneville, A., 2006. Off-shore evidence for a huge landslide of the northern flank of Tahiti-Nui (French Polynesia). Geochem. Geophys. Geosyst. 7 (3), 1-12.

Hildenbrand, A., Madureira, P., Marques, F.O., Cruz, I., Henry, B., Silva, P., 2008a. Multi-stage evolution of a sub-aerial volcanic ridge over the last 1.3 Myr: S. Jorge Island, Azores Triple Junction. Earth Planet. Sci. Lett. 273, 289-298.

Hildenbrand, A., Gillot, P.Y., Marlin, C., 2008b. Geomorphological study of long-term erosion on a tropical volcanic ocean island: Tahiti-Nui (French Polynesia), Geomorphology, 93 (3-4), 460481.

Hildenbrand, A., Marques, F.O., Costa, A.C.G., Sibrant, A.L.R., Silva, P.F., Henry, B., Miranda, J.M., Madureira, P., 2012a. Reconstructiong the architectural evolution of volcanic island from combined K/Ar, morphologic, tectonic, and magnetic data: The Faial Island example (Azores). J. Volc. Geotherm. Res. 241-242, 39-48.

Hildenbrand, A., Marques, F.O., Catalão, J., Catita C.M.S., Costa, A.C.G., 2012b. Large-scale active slump of the southeastern flank of Pico Island, Azores. Geology 40, 939-942, doi:10.1130/G33303.1.

Hildenbrand, A., Marques, F.O., Costa, A.C.G., Sibrant, A.L.R., Silva, P.F., Henry, B., Miranda, J.M., Madureira, P., 2013a. Reply to the comment by Quartau and Mitchell on "Reconstructiong the architectural evolution of volcanic island from combined K/Ar, morphologic, tectonic, and magnetic data: The Faial Island example (Azores)," J. Volc. Geotherm. Res. 241-242, 39-48, by Hildenbrand et al. (2012) in J. Volc. Geotherm. Res. 255, 127-130. 
Hildenbrand, A., Marques, F.O., Catalão, J., Catita C.M.S., Costa, A.C.G., 2013b. Reply to the comment by Quartau and Mitchell on " Large-scale active slump of the southeastern flank of Pico Island, Azores,” Geology 40, 939-942, doi:10.1130/G33303.1, by Hildenbrand et al., 2012) in Geology 41, doi:10.1130/G34879Y.1.

Hildenbrand, A., Weis, D., Madureira, P., Marques, F.O. 2014. Recent plate re-organization at the Azores Triple Junction: evidence from new geochemical and geochronological data on Faial, S; Jorge and Terceira volcanic islands. In press.

Hipólito, A., Madeira, J., Carmo, R., Gaspar, J.L., 2011. Neotectonics of Graciosa Island (Azores) Uncertainty in seismic hazard assessment in a volcanic area with variable slip-rates. $2^{\text {nd }}$ INQUAIGCP-567 International Workshop on Active Tectonics, Earthquake Geology, Archaeology and Engineering, Corinth, Greece.

Hopper, J.R., Buck, R.W., 1996. The effect of lower crust flow on continental extension and passive margin formation. J. Geophys. Res. 101, 20175-20194.

Hora, J.M., Singer, B.S., Wörner, G., 2007. Volcano evolution and eruptive flux on the thick crust of the Andean Central Volcanic Zone: ${ }^{40} \mathrm{Ar} /{ }^{39} \mathrm{Ar}$ constraints from Volcan Parinacota, Chile. GSA Bull. 119, 343-362.

Huismans, R., Beaumont, C., 2011. Depth-dependant extension, two-stage breakup and cratonic underplating at rifting margin. Nature 473 (7345), 74-78.

Jean Baptiste, P., Allard, P., Coutinho, R., Ferreira, T., Fourré, E., Queiroz, G., Gaspar, J.L., 2009. Helium isotopes in hydrothermal volcanic fluids of the Azores archipelago. Earth Planet. Sci. Lett. $281(1-2), 70-80$.

Johnson, C.L., Wijbrans, J.R., Constable, C.G., Gee, J., Staudigel, H., Tauxe, L., Forjaz, V.H., Salgueiro, M., 1998. 40Ar/39Ar ages and paleomagnetism of São Miguel Lavas, Azores. Earth Planet. Sci. Lett. 160, 637-649. 
Kirby, M.X., Jones, D.S., Avila, S.P., 2007. Neogene shallow-marine paleoenvironments and preliminary strontium isotope chronostratigraphy of Santa Maria island, Azores. Açoreana 5, $112-125$.

Krause, D.C., Watkins, N.D., 1970. North Atlantic crustal genesis in the vicinity of the Azores. Geophys. J. R. Astron. Soc. 19, 261-283.

Kröchert, J., Marurer, H., Buchner, E., 2008. Fossil beaches as evidence for significant uplift of Tenerife, Canary Islands. J. Afr. Earth Sci. 51 (4), 220-234.

Kurz, M.D., Jenkins, W.J., Schilling, J.G., Hart, S.R., 1982. Helium isotopic variations in the mantle beneath the central North Atlantic Ocean. Earth Planet. Sci. Lett. 58, 1-14.

Lahitte, P., Samper, A., Quidelleur, X., 2012. DEM-based reconstruction of Southern Basse Terre volcanoes (Guadeloupe archipelago, FWI): a contribution to the Lesser Antilles Arc volumetric extrusion and erosion rates. Geomorphology, 136, 148-164.

Laughton, A.S., Whitmarsh, R.B., Rusby, J.S.M., Somers, M.L., Revie, J., McCartney, B.S., Nafe, J.E., 1972. A continuous East-West Fault on the Azores-Gibraltar Ridge. Nature 237, 217-

Leslie, S.C., Moore, G.F., Morgan, J.K., 2004. Internal structure of Puna Ridge: evolution of the submarine East Rift Zone of Kilauea Volcano, Hawaii. J. Volc. Geotherm. Res. 129 (4), 237259.

Lipman, P.W., Normark, W.R., Moore, J.G., Wilson J.B., Gutmacher, C.E., 1988. The giant submarine Alika debris slide, Mauna Loa, Hawaii. J. Volc. Geortherm. Res. 93, 4279-4299.

Longpré, M.A., Troll, V.R., Walter, T.R., Hansteen, T.H., 2010. Volcanic and geochemical evolution of the Teno massid, Tenerife, Canary Isalnds: Some repercussions of giant landslides on ocean island magmatism. Geochem. Geophys. Geosyst. 10, q12017. http://dx.doi.org/10.10.29/2009GC002892.

Lourenço, N., Luis, J.F., Miranda, J.M., Ribeiro, A., Victor, L.A.M., 1998. Morpho-tectonic analysis of the Azores volcanic plateau from new bathymetric compilation of the area. Mar. Geophys. Res. 20, 141-156. 
Luís, J.F., Miranda, J., Patriat, P., Galdeano, A., Rossignol, J.C., Mendes-Victor, L., 1994. Açores Triple junction Evolution in the last 10Ma from a New AeromagneticSurvey. Earth Planet. Sci. Lett. 125, 439-459.

Luis, J.F., Miranda, J.M., Galdeano, A., Patriat, P., 1998. Constraints on the structure of the Azores spreading center from gravity data. Mar. Geophys. Res. 20, 157-170.

Machado, F., 1959. Submarine pits of the Azores plateau. Bull. Volcanol. 21, 109-116.

Madeira, J., 1986. Geologia estructural e enquadramento geotectonico da ilha de Santa Maria (Açores). M.Sc Thesis, Univ. Lisbon, 107pp.

Madeira, J., Ribeiro, A., 1990. Geodynamic models for the Azores triple junction: A contribution from tectonics. Tectonophysics 184 (3-4), 405 - 415.

Maia, M., Goslin, J., Gente, P., 2007. Evolution of the accretion processes along the Mid-Atlantic Ridge north of the Azores since 5.5 Ma: An insight into the interactions between the ridge and the plume. Geochm. Geophys. Geosyst. 8 (3), Q03013, doi:10.1029/2006GC001318.

Manconi, A., Longpré, M.-A., Walter, T.R., Troll, V.R., Hansteen, T.H., 2009. The effects of flank collapses on volcano plumbing systems. Geology 24, 321-234.

Marques, F.O., Catalão, J.C., DeMets, C., Costa, A.C.G., Hildenbrand, A., 2013a. GPS and tectonic evidence for a diffuse plate boundary at the Azores triple junction. Earth Planet. Sci. Lett. 381, 177-187.

Marques, F.O., Sibrant, A.L.R., Hildenbrand, A., Costa, A.C.G., 2013b. Large-scale sector collapses in the evolution of Santa Maria Island, Azores. Abstract Meeting AGU, 2013.

Marques, F.O., Catalão, J.C., DeMets, C., Costa, A.C.G., Hildenbrand, A., 2014a. corrigendum to: GPS and tectonic evidence for a diffuse plate boundary at the Azores triple junction, (Earth Planet. Sci. Lett. 381, 177-187) Earth Planet. Sci. Lett. 387, 1-3.

Marques, F.O., Catalão, J., Hildenbrand, A., Costa, A.C.G., Dias, N.A., 2014b. The 1998 Faial earthquake, Azores: Evidence for a transform fault associated with the Nubia-Eurasia plate boundary? Tectonophysics in press. 
Martinod, J., Davy, P., 1992. Periodic instabilities during compression or extension of the lithosphere: 1 deformation modes from an analytical perturbation method. J. Geophys. Res. 97 , $199-2014$.

Masson, D.G., Le Bas, T.P., Grevemeyer, I., Weinrebe, W., 2008. Flank collapse and large-scale landsliding in the Cape Verde Islands, off West Africa. Geochem. Geophys. Geosyst. 9 (Q07015). Doi:10/1029/2008GC001983.

McKenzie, D., 1972. Active Tectonics of the Mediterranean region. Geophys. J. R. Astron. Soc. 30, 109-185.

Métrich, N., Zanon, V., Créon, L., Hildenbrand, A., Moreira, M., Marques, F.O., 2014. Is the "Azores hotspot" a wetspot? Insights from geochemistry of fluid and melt inclusions in olivine of Pico basalt. J. Petrol. 55, 377-393.

Moore, J.G., Clague, D.A., Holcomb, R.T., Lipman, P.W., Normak, W.R., Torresan, M.E., 1989. Prodigious submarine landslides on the Hawaiian Ridge. J. Geophys. Res. Solid Earth 94 (B12), 17465-17484, doi:/10.1029/JB094iB12p17465.

Moore, J.G., Bryan, W.B., Beeson, M.H., Normak, W.R., 1995. Giant blaocks in the South Kona landslide, Hawaii. Geology $23 \quad$ (2), 125-128, doi:/10.1130/00917613(1995)023<0125/GITSK>2.3.CO;2.

Moreira, M., Allegre, J.C., 2002. Rare gas systematics an Mid Atlantic ridge $\left(37^{\circ}-40^{\circ} \mathrm{N}\right)$. Earth Planet. Sci. Lett. 198 (3-4), 401-416.

Muller, O., Pollard, D.D., 1977. The stress state near Spanish Peaks, Colorado determined from a dike pattern. Pure Appl. Geophys. 115, 69-86.

Nakamura, K., 1977. Volcanoes as possible indicators of tectonic stress orientation - principle and proposal. J. Volc. Geotherm. Res. 2, 1-16.

Navarro, A., Lourenço, N., Chorowicz, J., Miranda, J.M., Catalao, J., 2009. Analysis of geometry of volcanoes and faults in Terceira Island (Azores): Evidence for reactivation tectonics at the EUR/AFR plate boundary in the Azores triple junction. Tectonophysics 465 (1-4), 98-113. 
Nicolosi, I., Ajello Caracciolo, F., Branca, S., Ventura, G., Chiappini, M., 2014. Volcanic conduit migration over a basement landslide at Mount Etna (Italy). Nature, Scientific Reports 4:5293, doi:10.1038/srep05293.

O'de, H., 1957. Mechanical analysis of the dike pattern of the Spanish Peaks area, Colorado. Bull. Geol. Soc. Am. 68, 567-576.

Perez-Gussinye, M., Morgan, J.P., Reston, T.J., Ranero, C.R., 2006. The rift to drift transition at non volcanic margins: Insights from numerical modelling. Earth Planet. Sci. Lett. 244 (1-2), 458-473.

Petit, C., Deverchère, J., 2006. Structure and evolution of the Baikal rift: a synthesis. Geochem. Geophys. Geosyst. 7 (Q11016). Doi:10/1029/2006GC001265.

Pinel, V., Albino, F., 2013. Consequences of volcano sector collapse on magmato storage zones: Insights from numerical modeling. J. Volc. Geotherm. Res. 252, 29-37.

Presley, T.K., Sinton, J.M., Pringle, M., 1997. Postshield volcanism and catastrophic mass wasting of the Waianae Volcano, Oahu, Hawaii. Bull Volc. 58, 597-616.

Quartau, R., Tempera, F., Mitchell, N.C., Pinheiro, L.M., Duarte, H., Brito, P.O., Bates C.R., Monteiro, J.H., 2012. Morphology of the Faial Island shelf (Azores): The interplay between volcanic, erosional, depositional, tectonic and mass-wasting processes. Geochem. Geophys. Geosyst. 13 (4), doi:10.1029/2011GC003987.

Quidelleur, X., Gillot, P.Y., Soler, V., Lefevre, J.C., 2001. K/Ar dating extended into the last millennium: Application to the youngest effusive episode of the Teide volcano (Canary islands, Spain). Geophys. Res. Lett. 28, 3067-3070.

Quidelleur, X., Hildenbrand, A., Samper, A., 2008. Causal link between Quaternary paleoclimatic changes and volcanic islands evolution. Geophys. Res. Lett. 35, L02303, doi:10.1029/2007GL031849.

Roman, A., Jaupart, C., 2014. The impact of volcanic edifice on intrusive and eruptive activity. Earth Planet. Sci. Lett., 408, 1-8. 
Ricci, J., Lahitte, P., Quidelleur, X., 2014. Construction and destruction rates of volcanoes within a tropical environment based on K-Ar dating and numerical reconstructions: examples from the Basse-Terre Island (Guadeloupe, Lesser Antilles). Geomorphology, doi:/10.1016/j.geomorph.2014.10.002.

Salvany, T., Lahitte, P., Nativel, P., Gillot, P.Y., 2012. Geomorphic evolution of the Piton des Neiges volcano (Reunion island, Indian Ocean): competition between volcanic construction and erosion since 1.4 Ma. Geomorphology, 136, 132-147.

Samper, A., Quidelleur, X., Komorowski, J.C., Lahitte, P., Bourdon, G., 2009. K-Ar constraints on the volcanic evolution of the Southern Basse Terre Area during the last 300 kyr. J. Volc. Geotherm. Res. 187, 117-130.

Schilling, J.G., 1975. Azores mantle blob: rare earth evidence. Earth Planet. Sci. Lett. 25, 103-115. Schilling, J.G., Zajac, M., Evans, R., Johnston, T., White, W., Devine, J.D., Kingsley, 1983. Petrology and chemical variations along the Mid-Atlantic Ridge from $29^{\circ} \mathrm{N}$ to $73^{\circ} \mathrm{N}$, Ame. J. Sci. $283,510-586$.

Schilling, J.G., 1985. Upper mantle heterogeneities and dynamics. Nature 314, 62-67.

Searle, R., 1980. Tectonic pattern of the Azores spreading centre and triple junction. Earth Planet. Sci. Lett. 51, 415-434.

Serralheiro, A., Alves, C.A.M., Forjaz, V.H., Rodrigues, B., 1987. Carta vulcanológica dos Açores, Ilha de Santa Maria. Escala 1:15000 (folhas 1 e 2): Serviço regional de Protecção Civil dos Açores e Universidade dos Açores (Ed.). Ponta Delgada, "Volcanic map of the Azores, Santa Maria islands. Scale 1:15000 (page 1 and 2): Service regional of the civil protection of the Azores and University of the Azores (Ed.). Ponta Delgada”.

Sibrant, A.L.R., Marques, F.O., Hildenbrand, A., 2014. Construction and destruction of a volcanic island developed inside an oceanic rift: Graciosa Island, Terceira Rift, Azores. J. Volc. Geotherm. Res. 284, 32-45.

Silva, P.F., Henry, B., Marques, F.O., Hildenbrand, A., Madureira, P., Mériaux A., Kratinova, Z., 
2012. Palaeomagnetic study of a subaerial volcanic ridge (Sao Jorge Island, Azores) for the past 1.3 Myr: evidence for the Cobb Mountain Subchron, volcano flank instability and tectonomagmatic implications. Geophys. J. Inter. 188, 959-978.

Silveira, G., Stutzmann, E., Davaille, A., Montagner, J.-P., Mendes-Victor, L., Sebai, A., 2006. Azores hotspot signature in the upper mantle. J. Volc. Geotherm. Res. 156, 23-34.

Silveira, G., Vinnik, L., Stutzmann, E., Farra, V., Kiselev, S., Morais, I., 2010. Stratification of the Earth beneath the Azores from P and S receiver functions. Earth Planet. Sci. Lett. 299 (1-2), 91-103.

Steiger, R.H., Jäger, E., 1977. Subcommission on geochronology: Convention on the use of decay constants in geo- and cosmochronology. Earth Planet. Sci. Lett. 36, 359-362.

Storetvedt, K.M., Serralheiro, A., Moreira, M., Abranches, M.C., 1989. Magnetic structure and evolution of the island of Santa Maria, Azores. Phys. Earth Planet. Inter. 58, 228-238.

Takada, A., 1999. Variations in magma supply and magma partitioning: the role of tectonic settings. Journal Volcano. Geotherm. Res. 93, 93-110.

Tibaldi, A., Bonali, F.L., Corazzato, C., 2014. The diverging volcanic rift system. Tectonophysics 611, 94-113.

Trippanera, D., Porreca, M., Ruch, J., Pimentel, A., Acocella, V., Pacheco, J., Salvatore, M. 2014. Relationships between tectonics and magmatism in a transtensive/transform setting: An example from Faial Island (Azores, Portugal). Geol. Soc. Am. Bull. 126 (1-2), 164-181. doi:10.1130/B30758.1

Vogt, P.R., Jung, W.Y., 2004. The Terceira Rift as hyper slow, hotspot dominated oblique spreading axis: A comparison with other slow spreading plate boundaries. Earth Planet. Sci. Lett., 218, 77-90.

Watts, A.B., Masson, D.G., 2001. New sonar evidence for recent catastrophic collapses of the north flank of Tenerife, Canary Islands. Bull. Volcanol., 63 (1), 8-19.

Zazo, C., Goy, J.L., Dabrio, C.J., Soler, V., Hillaire-Marcel, C, Ghaleb, B., Gonzalez-Delgado, J.A., 
Bardaji, T., Cazbero, A., 2006. Quaternary marine terraces on Sal Island (Cape Verde archipelago).

Zbyszewski, G., Ferreira, O.V., 1960. Carta geológica de Portugal, Ilha de Santa Maria (Açores), scale 1:50 000: Serviços Geológicos de Portugal. 


\section{FIGURE CAPTIONS}

Figure 1. Bathymetric map of the Azores (data from Lourenço et al., 1998). The thick black lines indicate the location of the Mid-Atlantic Ridge (MAR) axis, which separate the North American and Eurasian plates, and the North American and Nubian plates. The white lines mark the current Eurasia/Nubia diffuse plate boundary (after Marques et al., 2013a, 2014a). The black dashed line indicates the location of the Terceira Rift (TR), and the white dashed line the East Azores Fracture Zone (EAFZ). Black numbers show previous geochronological data on volcanic rocks from the eastern and central islands (Féraud et al., 1980; Chovelon, 1982; Johnson et al., 1998; Calvert et al., 2006; Hildenbrand et al., 2008a, 2012a; Sibrant et al., 2014). The inset shows the location of the Azores archipelago in the Atlantic Ocean. Bathymetric GF: Gloria Fault (on the inset); Cor: Corvo; Flo: Flores; Fai: Faial; Pic: Pico; SJo: S. Jorge; Gra: Graciosa; Ter: Terceira; SMi: S. Miguel; SMa: Santa Maria.

Figure 2. Geological map of Santa Maria adapted from Serralheiro et al. (1987). The white circle indicates the location of the Airport, the higher point of Pico Alto and the city of Anjos, San Lourenço, and Vila do Porto.

Figure 3. Shaded relief map of Santa Maria Island generated from a high-resolution DEM (10 m). Dikes measured in this study are shown in purple and red for the western and eastern parts of the island, respectively and the black dashed lines indicates the previous reported measurements (and localized) by Zbyszewski and Ferreira (1960) on their geological map. Thick dashed black lines show interpreted scarps, and dashed triangles scoria cones. The thin dashed line indicates the location of the inferred faults reported by Madeira and Ribeiro, (1990). The thicker line indicates our faults measurements. Stereoplots show orientation of dikes for the western and the eastern parts of the island, from our measurements and previous measurements (Madeira, 1986). Black squares indicate the location of Figs. 7, 8, 9 and A1. 
Figure 4. (A) Slope map of Santa Maria Island. The black and white lines indicates the location of the cross-section shows in (B), (C) and (D). (B) N-S Cross-section across the Older Shield Volcano. (C) N-S cross-section across the Younger Shield Volcano. (D) W-E cross-section across the two recognized volcanic complex, which constitute Santa Maria island.

Figure 5. Stratigraphic relationships between the three main units of Santa Maria and the Facho complex.

Figure 6. (A) Preferred geological map of Santa Maria, simplified after Zbyszewski and Ferreira (1960) and Serralheiro et al. (1987). Circles show the location of our samples and our new K-Ar ages. Note the distribution of volcanic and volcano-sedimentary units and their dip. (B) E-W crosssection summarizing our field observations and interpretation. Vertical exaggeration $=20$.

Figure 7. Sea cliff along the SW tip of Santa Maria, close to Vila do Porto (see Fig. 3 for location). The picture shows lava flows of the Old Shield Volcano intruded by dikes. Note that the dikes are sealed at the top by younger lava flows.

Figure 8. Base of the sea cliff along the SE part of Santa Maria (see Fig. 3 for location). The picture shows alternating sedimentary deposits (SD) and lava flows, including pillow-lavas (PL). Red circles show the position of our samples SA12L and SA12M, from lava flows below and above sedimentary deposits, respectively. Notice the local E dip of the flows.

Figure 9. Normal fault dipping to the east (right) cutting the eastern volcanic succession, which we dated in this study between 4.32 Ma and 3.94 Ma (see Fig. 3 for location).

Figure 10. Cartoon illustrating the evolution of Santa Maria. The blue line represents sea level. 
Table 1. Dikes new measurements realized in the present study and their location in UTM units.

Table 2. New K-Ar determinations obtained with the unspiked Cassignol-Gillot technique on freshseparated groundmass. For each sample, the mean age is obtained by weighing by the amount of radiogenic argon. Uncertainties quoted at the $1 \sigma$ level.

Supplementary Material, Figure A1. Fieldwork pictures of the Feteiras formation. (A) lateritic surface of the Feteiras formation and (B) picture indicates the progressive alteration of the initial lava flows in lateritic ground surface. 


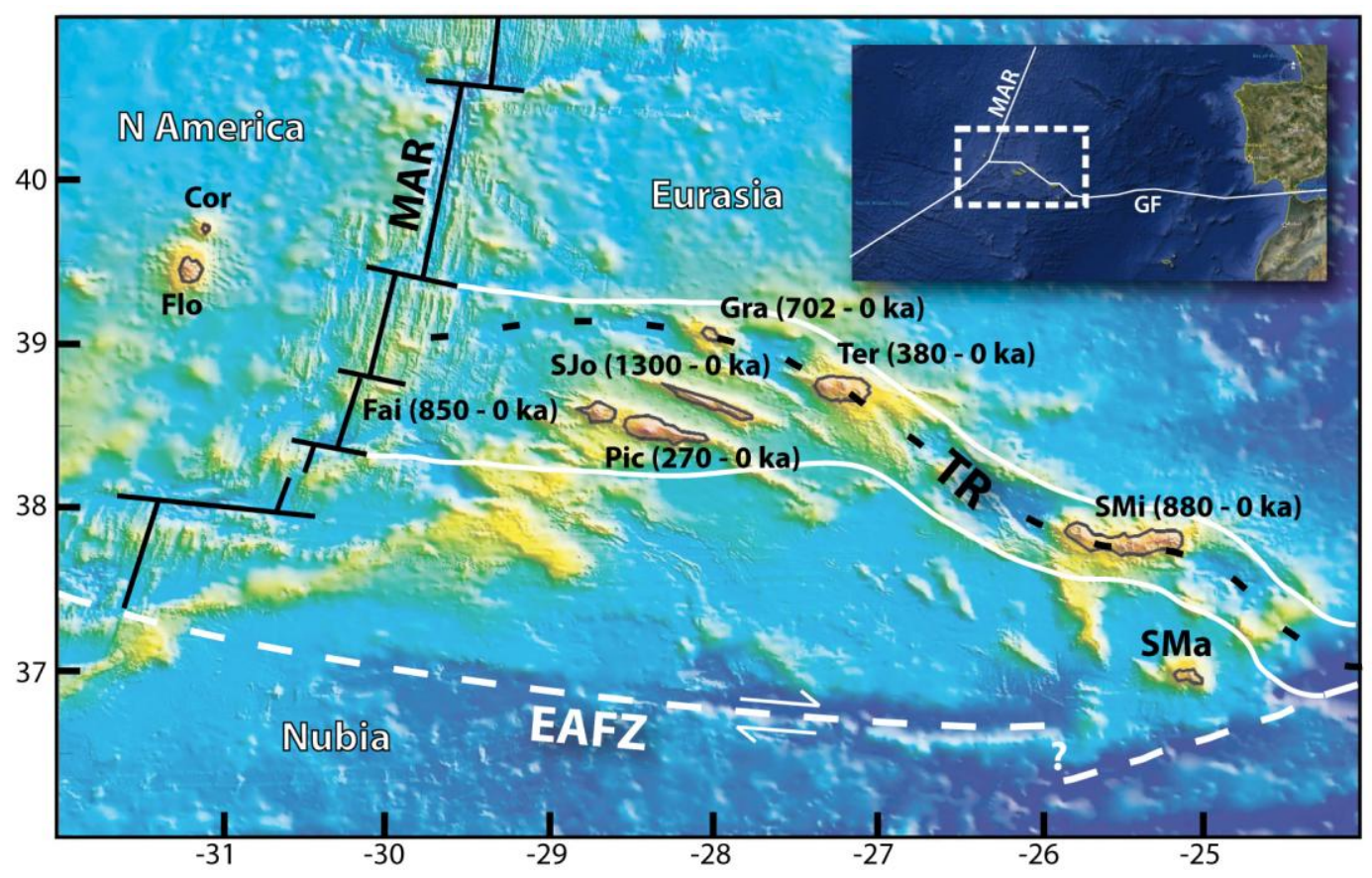

Fig 1 


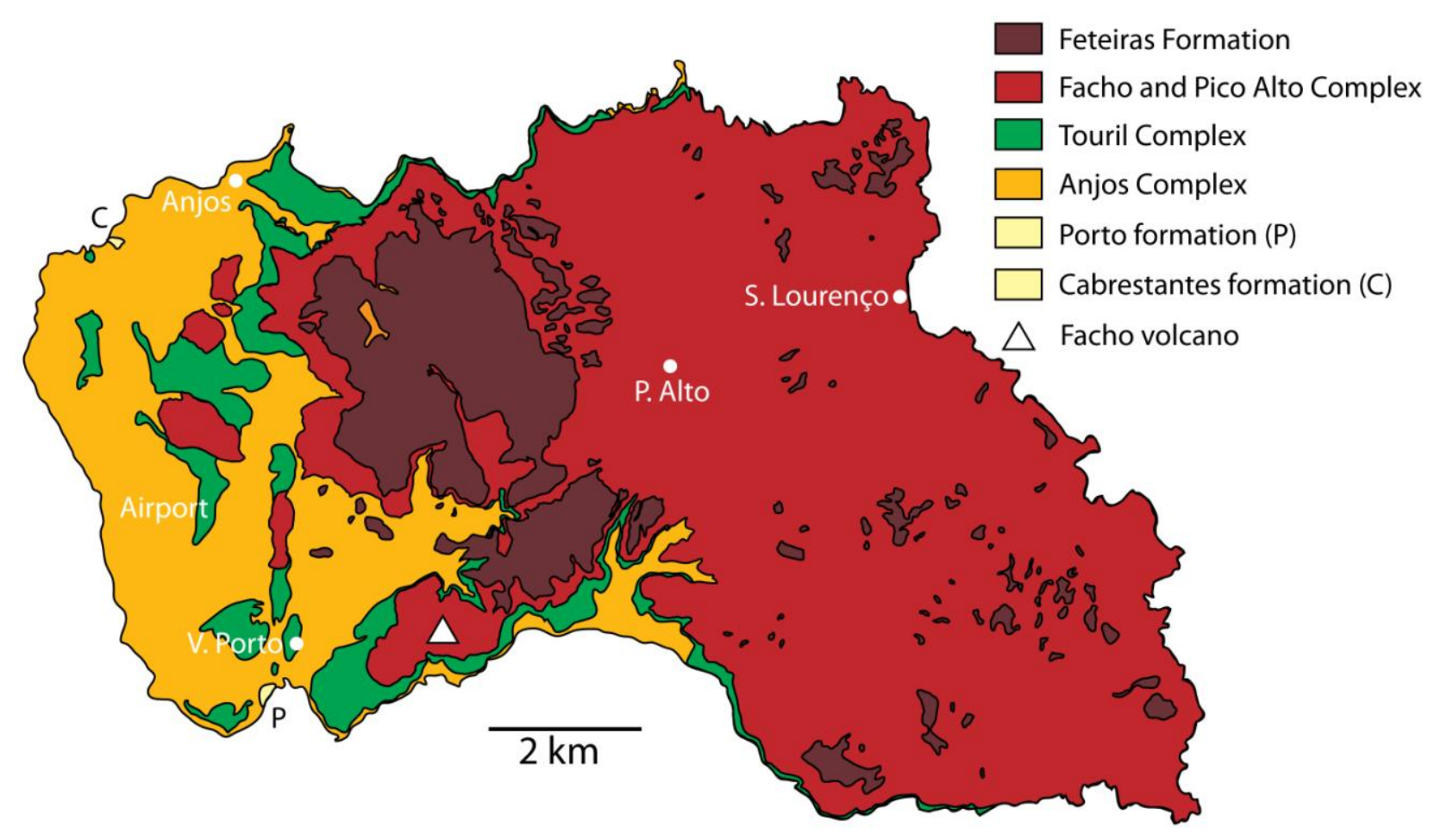

Fig 2 


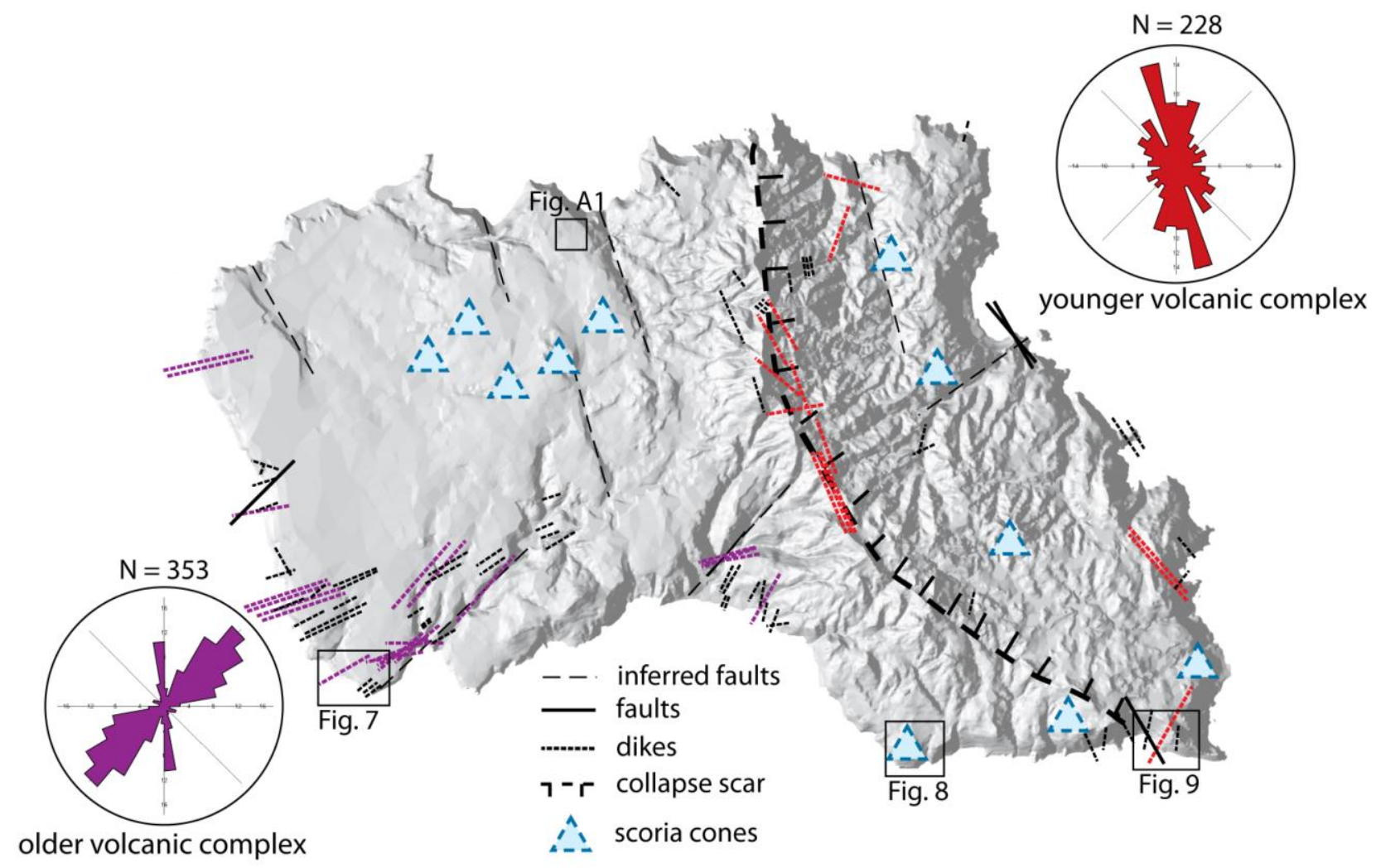

Fig 3 


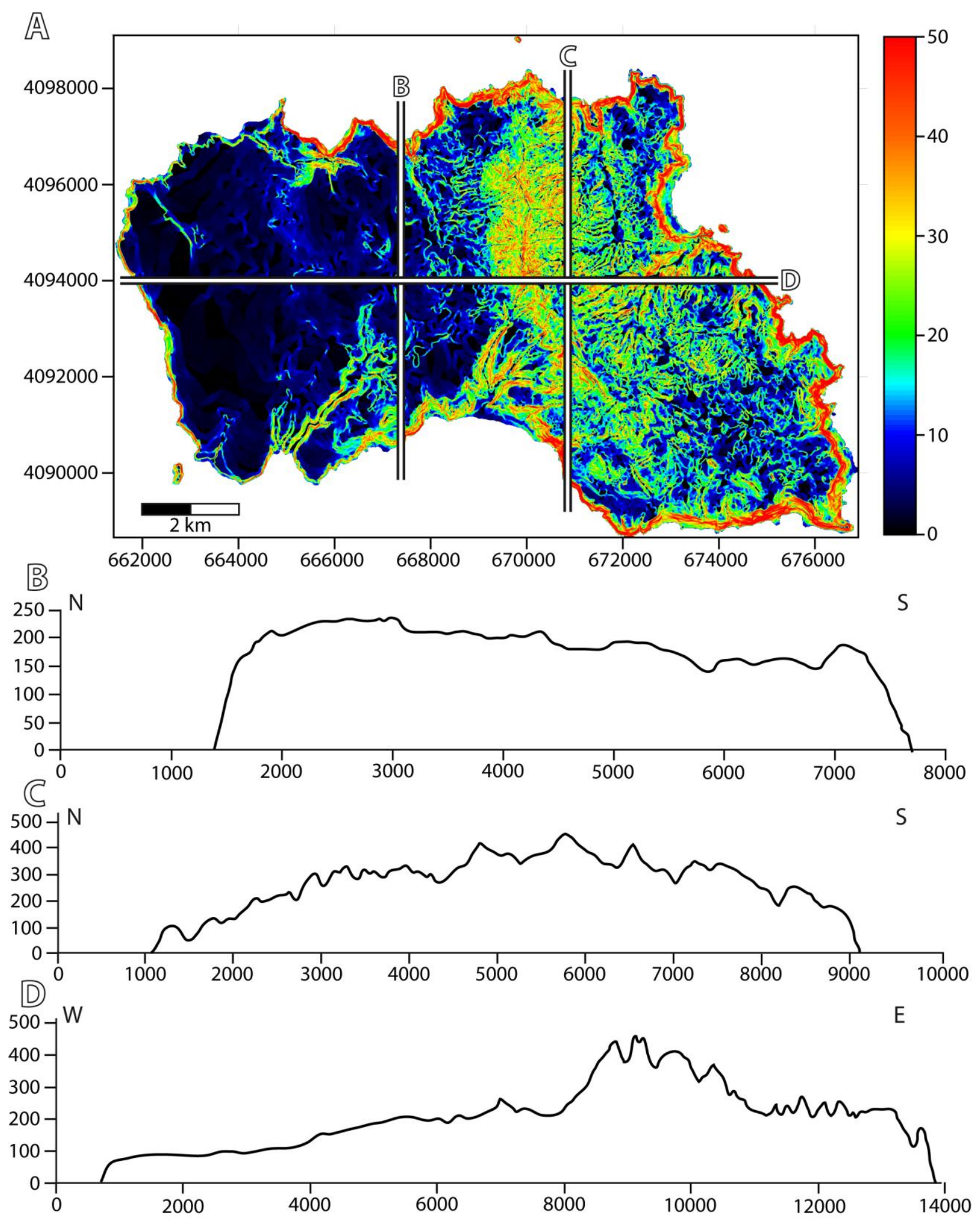

Fig 4 


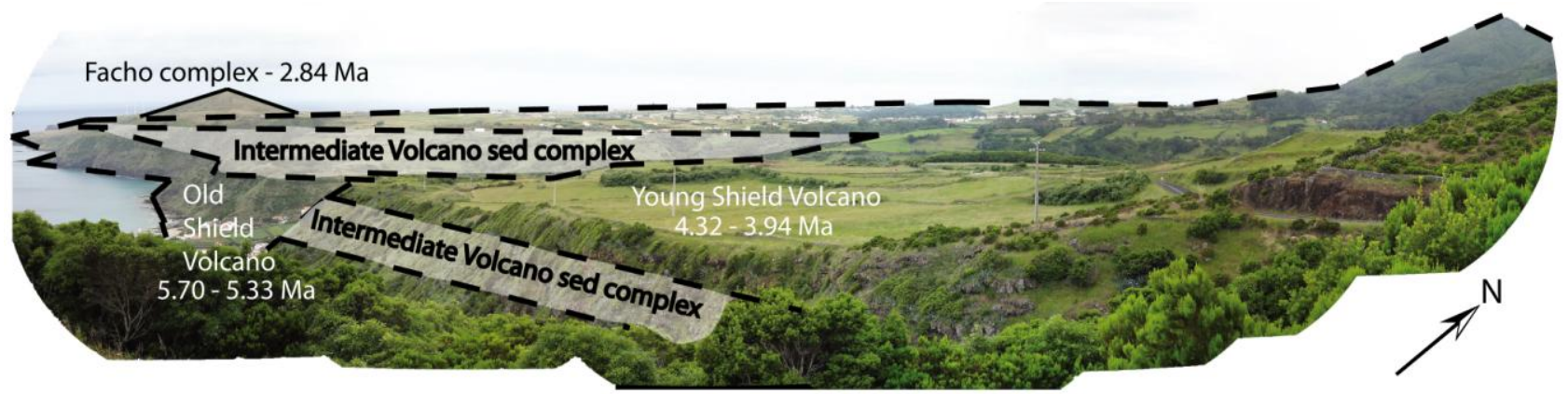

Fig 5 


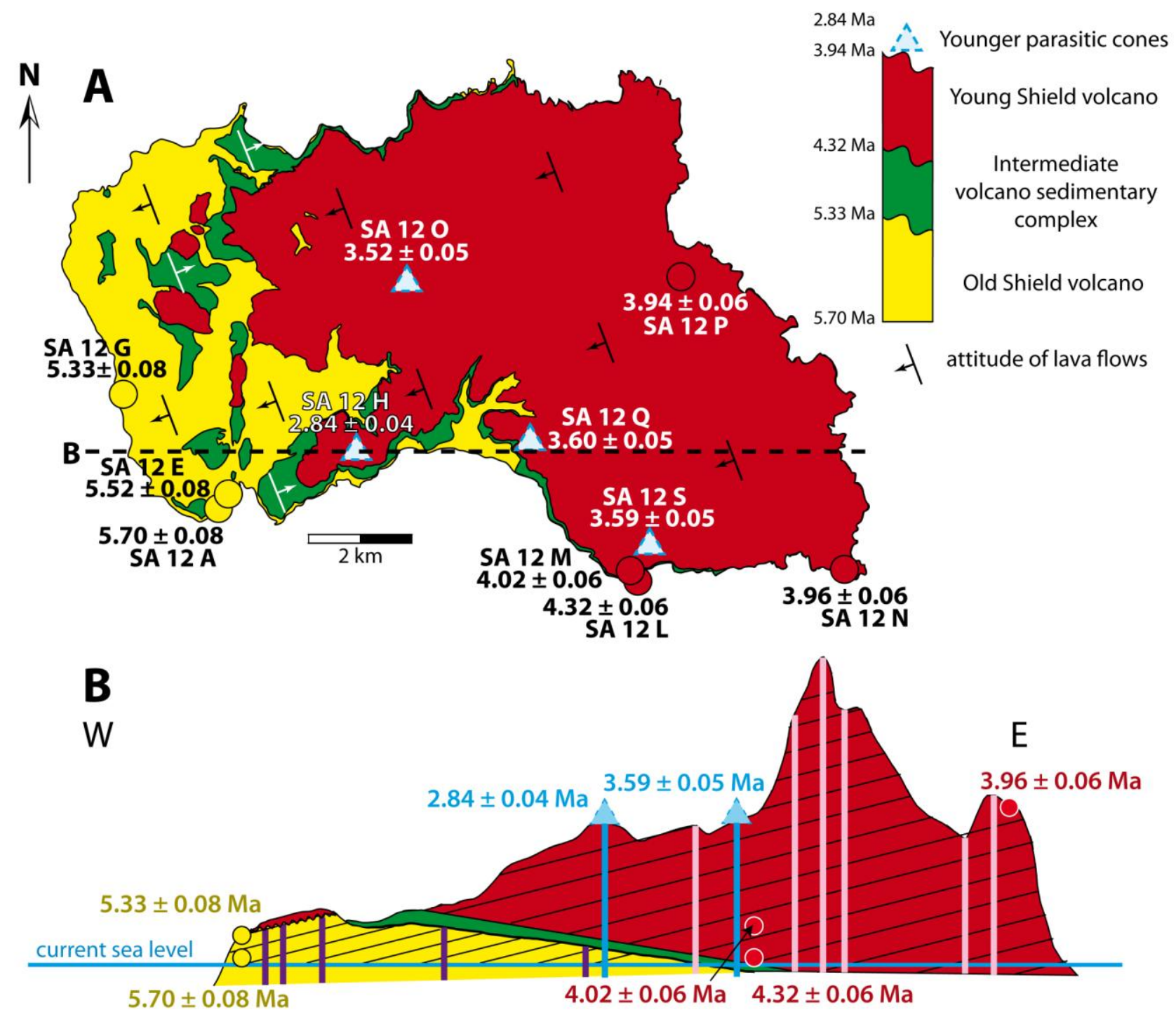

Fig 6 


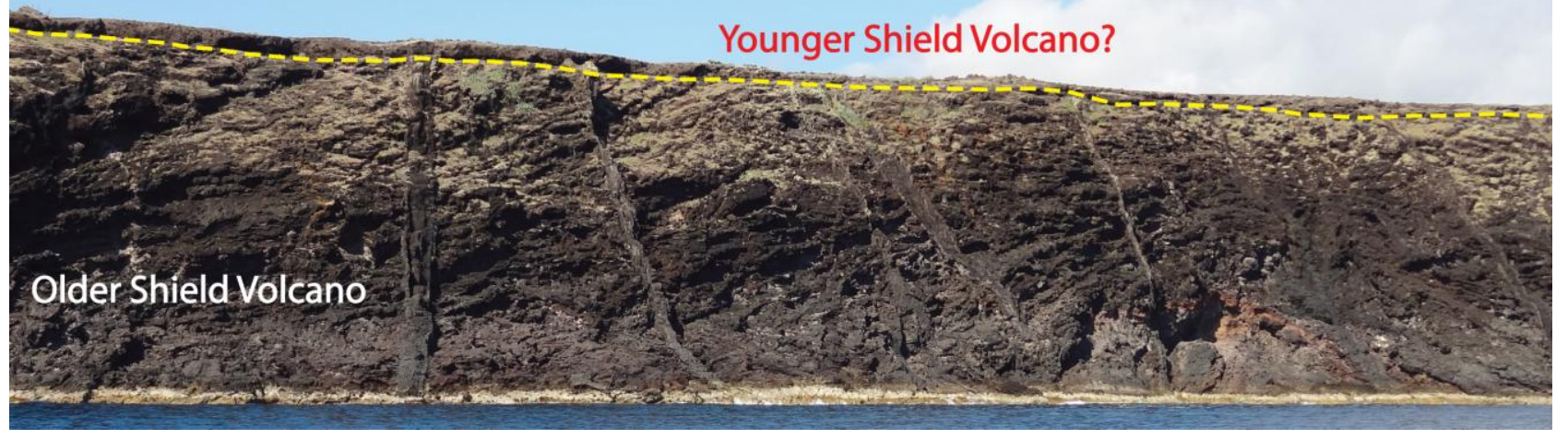

Fig 7 


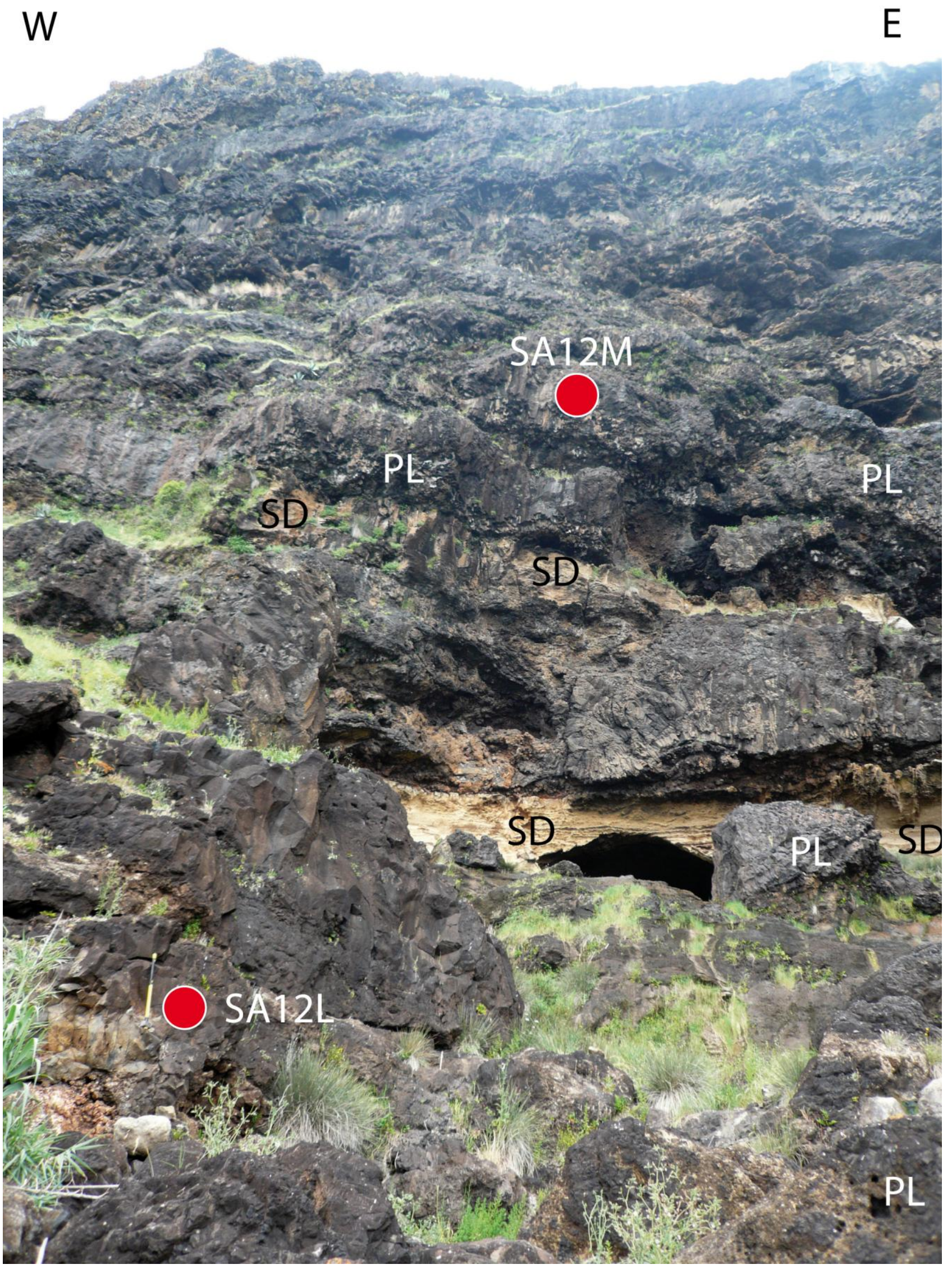

Fig 8 


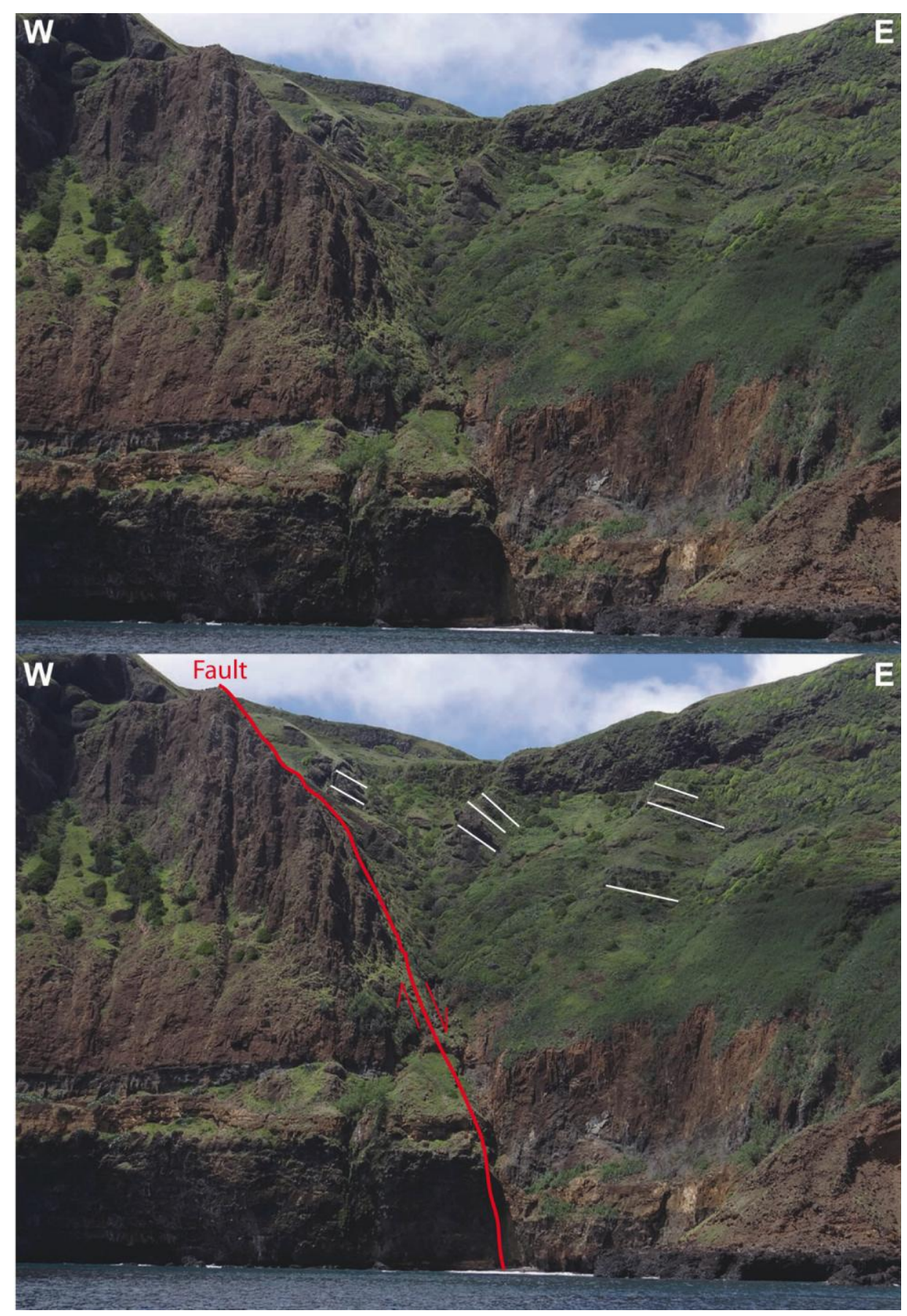

Fig 9 


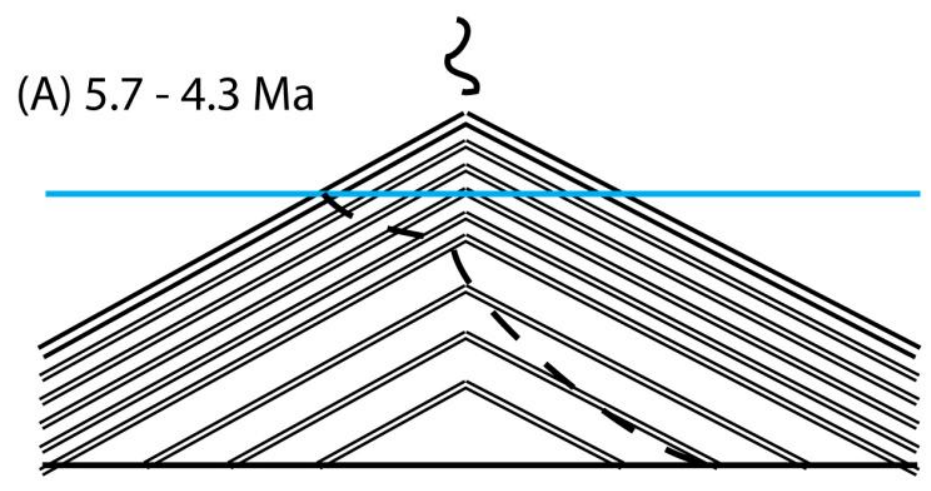

(B) $4.3-4.0 \mathrm{Ma}$

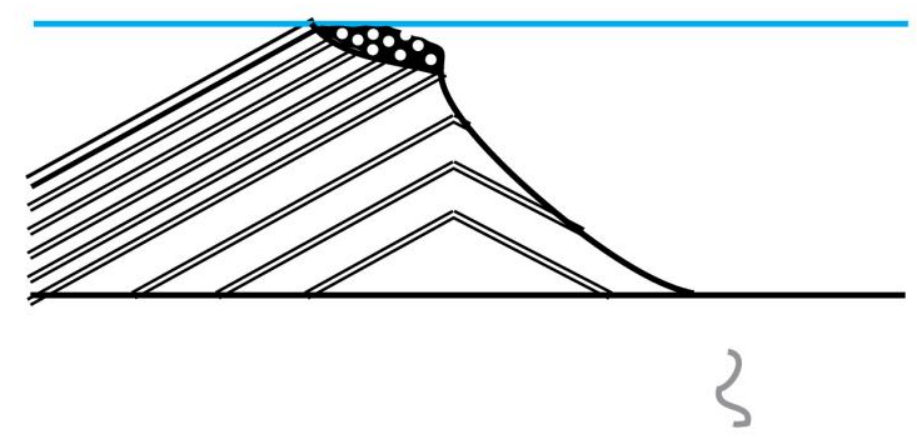

(C) $4.0-3.9 \mathrm{Ma}$

(D) $3.9-2.8 \mathrm{Ma}$

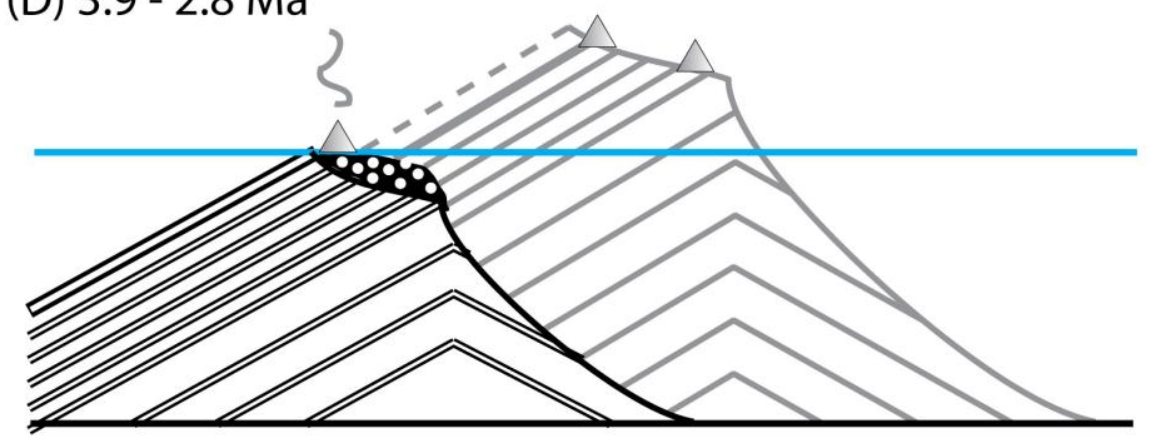

Fig 10 
Table 1

DIKES

\begin{tabular}{|c|c|c|c|c|}
\hline UTM 26E & UTM N & strike $(\mathbf{N})$ & $\operatorname{dip}\left({ }^{\circ}\right)$ & thickness (m) \\
\hline 664644 & 4090347 & 50 & 90 & 3 \\
\hline 664628 & 4090302 & 50 & $80 \mathrm{SE}$ & 4,5 \\
\hline 664633 & 4090327 & 70 & 90 & 0,5 \\
\hline 664609 & 4090243 & 65 & 90 & 4 \\
\hline 664593 & 4090220 & 80 & $65 \mathrm{~S}$ & 0,25 \\
\hline 664593 & 4090220 & 75 & 90 & 3 \\
\hline 664594 & 4090200 & 50 & 90 & 3 \\
\hline 664592 & 4090190 & 60 & 90 & 2 \\
\hline 664628 & 4090302 & 60 & 90 & 0,5 \\
\hline 664628 & 4090302 & 70 & 90 & 0,5 \\
\hline 664964 & 4090498 & 90 & 90 & 1,5 \\
\hline 662605 & 4092350 & 80 & 90 & 1 \\
\hline 662605 & 4092350 & 100 & 90 & 1 \\
\hline 666984 & 4091091 & 100 & 90 & 2 \\
\hline 666984 & 4091091 & 130 & 90 & 1 \\
\hline 666984 & 4091091 & 130 & 90 & 1 \\
\hline 669010 & 4091670 & 75 & 90 & 1,5 \\
\hline 669028 & 4091652 & 60 & 83SE & 0,5 \\
\hline 669028 & 4091652 & 40 & $85 \mathrm{SE}$ & 1 \\
\hline 669037 & 4091649 & 45 & 90 & 0,3 \\
\hline 669038 & 4091648 & 50 & $83 \mathrm{SE}$ & 1 \\
\hline 669041 & 4091647 & 70 & 80SE & 0,8 \\
\hline 669048 & 4091643 & 80 & 90 & 2 \\
\hline 669062 & 4091637 & 90 & 90 & 3 \\
\hline 669084 & 4091643 & 60 & 90 & 2,5 \\
\hline 669925 & 4094615 & 130 & 80NE & 0,7 \\
\hline 670243 & 4094044 & 80 & $85 \mathrm{~N}$ & 1 \\
\hline 670510 & 4096473 & 65 & $82 \mathrm{SW}$ & 0,5 \\
\hline 670519 & 4096466 & 20 & $85 \mathrm{~W}$ & 1 \\
\hline 670088 & 4097478 & 80 & $85 \mathrm{NW}$ & 0,5 \\
\hline 670092 & 4097465 & 105 & $50 \mathrm{~N}$ & 0,3 \\
\hline 670090 & 4097456 & 75 & $85 \mathrm{~S}$ & 2,5 \\
\hline
\end{tabular}


Table 2

\begin{tabular}{|c|c|c|c|c|c|c|c|}
\hline Sample & UTM 26 E & UTM N & $\mathrm{K} \%$ & $40 \operatorname{Ar}^{*}(\%)$ & $40 A r^{*}\left(10^{12} \mathrm{at} / \mathrm{g}\right)$ & Age (Ma) & Unc. (Ma) \\
\hline SA12B & 664691 & 4090402 & 0.971 & $\begin{array}{l}26.8 \% \\
33.0 \%\end{array}$ & $\begin{array}{l}5.853 \\
5.741\end{array}$ & $\begin{array}{l}5.76 \\
5.65 \\
\mathbf{5 . 7 0}\end{array}$ & $\begin{array}{l}0.08 \\
0.08 \\
\mathbf{0 . 0 8}\end{array}$ \\
\hline SA12E & 664691 & 4090402 & 1.382 & $\begin{array}{l}49.5 \% \\
43.9 \%\end{array}$ & $\begin{array}{l}7.966 \\
8.010\end{array}$ & $\begin{array}{l}5.51 \\
5.54 \\
\mathbf{5 . 5 2}\end{array}$ & $\begin{array}{l}0.08 \\
0.08 \\
\mathbf{0 . 0 8}\end{array}$ \\
\hline SA12G & 662605 & 4092350 & 0.729 & $\begin{array}{l}36.8 \% \\
57.8 \%\end{array}$ & $\begin{array}{l}4.123 \\
4.021\end{array}$ & $\begin{array}{l}5.41 \\
5.27 \\
\mathbf{5 . 3 3}\end{array}$ & $\begin{array}{l}0.08 \\
0.08 \\
\mathbf{0 . 0 8}\end{array}$ \\
\hline SA12L & 672509 & 4088860 & 1.025 & $\begin{array}{l}40.5 \% \\
40.7 \%\end{array}$ & $\begin{array}{l}4.648 \\
4.617\end{array}$ & $\begin{array}{l}4.34 \\
4.31 \\
\mathbf{4 . 3 2}\end{array}$ & $\begin{array}{l}0.06 \\
0.06 \\
\mathbf{0 . 0 6}\end{array}$ \\
\hline SA12M & 672509 & 4088860 & 1.067 & $\begin{array}{l}24.3 \% \\
28.5 \%\end{array}$ & $\begin{array}{l}4.529 \\
4.445\end{array}$ & $\begin{array}{l}4.06 \\
3.98 \\
4.02\end{array}$ & $\begin{array}{l}0.06 \\
0.06 \\
\mathbf{0 . 0 6}\end{array}$ \\
\hline SA12N & 676542 & 4088923 & 1.110 & $\begin{array}{c}8.9 \% \\
18.4 \%\end{array}$ & $\begin{array}{l}4.544 \\
4.622\end{array}$ & $\begin{array}{l}3.92 \\
3.98 \\
3.96\end{array}$ & $\begin{array}{l}0.07 \\
0.06 \\
\mathbf{0 . 0 6}\end{array}$ \\
\hline SA12P & 673336 & 4094610 & 0.756 & $\begin{array}{l}16.1 \% \\
38.8 \%\end{array}$ & $\begin{array}{l}3.182 \\
3.081\end{array}$ & $\begin{array}{l}4.03 \\
3.90 \\
3.94\end{array}$ & $\begin{array}{l}0.06 \\
0.06 \\
\mathbf{0 . 0 6}\end{array}$ \\
\hline SA12Q & 670441 & 4091421 & 0.693 & $\begin{array}{l}35.2 \% \\
29.5 \%\end{array}$ & $\begin{array}{l}2.609 \\
2.615\end{array}$ & $\begin{array}{l}3.60 \\
3.61 \\
\mathbf{3 . 6 0}\end{array}$ & $\begin{array}{l}0.05 \\
0.05 \\
\mathbf{0 . 0 5}\end{array}$ \\
\hline SA12S & 672714 & 4089409 & 0.610 & $\begin{array}{l}14.8 \% \\
31.0 \%\end{array}$ & $\begin{array}{l}2.308 \\
2.279\end{array}$ & $\begin{array}{l}3.62 \\
3.57 \\
3.59\end{array}$ & $\begin{array}{l}0.06 \\
0.05 \\
\mathbf{0 . 0 5}\end{array}$ \\
\hline SA12O & 668132 & 4094528 & 0.803 & $\begin{array}{l}41.1 \% \\
43.3 \%\end{array}$ & $\begin{array}{l}2.950 \\
2.960\end{array}$ & $\begin{array}{l}3.51 \\
3.52 \\
\mathbf{3 . 5 2}\end{array}$ & $\begin{array}{l}0.05 \\
0.05 \\
\mathbf{0 . 0 5}\end{array}$ \\
\hline SA12H & 667044 & 4091159 & 0.466 & $\begin{array}{l}13.3 \% \\
16.0 \%\end{array}$ & $\begin{array}{l}1.376 \\
1.392\end{array}$ & $\begin{array}{r}2.82 \\
2.86 \\
\mathbf{2 . 8 4}\end{array}$ & $\begin{array}{l}0.05 \\
0.04 \\
\mathbf{0 . 0 4}\end{array}$ \\
\hline
\end{tabular}

